\title{
Calcium Increase and Substance P Release Induced by the Neurotoxin Brevetoxin-1 in Sensory Neurons: Involvement of PAR2 Activation through Both Cathepsin $\mathrm{S}$ and Canonical Signaling
}

\author{
Ophélie Pierre ${ }^{1, *}\left(\mathbb{D}\right.$, Maxime Fouchard ${ }^{1,2}$, Paul Buscaglia ${ }^{3}\left(\mathbb{D}\right.$, Nelig Le Goux $^{3}$, \\ Raphaël Leschiera ${ }^{1}$, Olivier Mignen ${ }^{3}\left(\mathbb{D}\right.$, Joachim W. Fluhr ${ }^{1,2,4}$, Laurent Misery ${ }^{1,2} \mathbb{C}$ \\ and Raphaële Le Garrec ${ }^{1}$ (D) \\ 1 EA4685 Laboratory of Interactions Neurons-Keratinocytes (LIEN), Faculty of Medicine and Health Sciences, \\ University Brest, F-29200 Brest, France; maxime.fouchard@gmail.com (M.F.); \\ raphael.leschiera@univ-brest.fr (R.L.); Joachim.Fluhr@charite.de (J.W.F.); laurent.misery@chu-brest.fr (L.M.); \\ rlegarrec@univ-brest.fr (R.L.G.) \\ 2 Department of Dermatology, University Hospital of Brest, F-29200 Brest, France \\ 3 InsermUMR1227, Lymphocytes B et Autoimmunity, University Brest, F-29200 Brest, France; \\ paul.buscaglia@gmail.com (P.B.); Nelig.LeGoux@univ-brest.fr (N.L.G.); olivier.mignen@univ-brest.fr (O.M.) \\ 4 Department of Dermatology and Allergology, Universitaetsmedizin Charit Berlin, D-10117 Berlin, Germany \\ * Correspondence: ophpierros@gmail.com; Tel.: +33-2-98018161
}

Received: 27 November 2020; Accepted: 15 December 2020; Published: 17 December 2020

check for updates

\begin{abstract}
Red tides involving Karenia brevis expose humans to brevetoxins (PbTxs). Oral exposition triggers neurotoxic shellfish poisoning, whereas inhalation induces a respiratory syndrome and sensory disturbances. No curative treatment is available and the pathophysiology is not fully elucidated. Protease-activated receptor 2 (PAR2), cathepsin S (Cat-S) and substance P (SP) release are crucial mediators of the sensory effects of ciguatoxins (CTXs) which are PbTx analogs. This work explored the role of PAR2 and Cat-S in PbTx-1-induced sensory effects and deciphered the signaling pathway involved. We performed calcium imaging, PAR2 immunolocalization and SP release experiments in monocultured sensory neurons or co-cultured with keratinocytes treated with $\mathrm{PbTx}-1$ or P-CTX-2. We demonstrated that PbTx-1-induced calcium increase and SP release involved Cat-S, PAR2 and transient receptor potential vanilloid 4 (TRPV4). The PbTx-1-induced signaling pathway included protein kinase A (PKA) and TRPV4, which are compatible with the PAR2 biased signaling induced by Cat-S. Internalization of PAR2 and protein kinase $C$ (PKC), inositol triphosphate receptor and TRPV4 activation evoked by PbTx-1 are compatible with the PAR2 canonical signaling. Our results suggest that $\mathrm{PbTx}$-1-induced sensory disturbances involve the PAR2-TRPV4 pathway. We identified PAR2, Cat-S, PKA, and PKC that are involved in TRPV4 sensitization induced by PbTx-1 in sensory neurons.
\end{abstract}

Keywords: brevetoxin; ciguatoxin; sensory disorders; substance P; cathepsin S; PAR2; biased pathway; canonical pathway

\section{Introduction}

Brevetoxins (PbTxs) are a family of cyclic and lipophilic polyether compounds. These phytoplanktonic neurotoxins are synthetized during algal blooms, especially during red tides involving Karenia brevis. PbTxs are accumulated in molluscs (e.g., oysters, mussels or clams) and could be aerosolized. The main routes of human exposure are the oral route, resulting in neurotoxic 
shellfish poisoning (NSP), and the inhaled route, resulting in a respiratory syndrome [1]. The largest outbreaks of NSP happened in the USA (North Carolina and Gulf of Mexico, especially Florida) and in New Zealand following red tides (algal blooming) [1]. NSP syndrome includes gastrointestinal symptoms and neurological signs such as abdominal pain, paresthesia, cold allodynia, vertigo, ataxia, muscle pain, weakness and headache [1,2]. Those symptoms occur within few minutes to several hours after seafood ingestion and last 1 to 3 days [2]. Currently, the NSP incidence is low due to prevention, information and the monitoring of algal blooming [3]. In contrast, airway irritation following respiratory $\mathrm{PbTx}$-exposure increase periodically including emergency room admissions [4]. Inhalation of $\mathrm{PbTx}$ aerosols result in respiratory symptoms especially in persons with underlying airway diseases such as asthma. Upper-airway symptoms include cough, sneezing and rhinorrhea, involving sensory fiber activation. Lower-airway symptoms include chest tightness, wheezing and shortness of breath [5-8]. Burning sensations in nose and throat, associated with itch on the facial skin, watery eyes and neurological symptoms such as headache, have been reported [9]. These symptoms support the hypothesis that PbTx exert sensory effects through inhalation. Current treatment is only symptomatic due to the lack of a specific antidote for PbTx intoxications. Climatic changes and global warming may increase the occurrence of algal blooming of K. brevis [10] and expand the affected areas in Europe [11]. Beyond effects on humans, PbTxs have destructive effects on the fauna including turtles [12], marine mammals [13-15], fishes and birds.

Currently, several PbTx derivatives have been identified [3], including PbTx-1 which is the most potent congener whereas PbTx-2 and PbTx-3 are the most abundant in aerosols [16,17]. Mechanistically, PbTxs interact with site 5 of the alpha subunit of the voltage-dependent sodium channels $\left(\mathrm{Na}_{\mathrm{V}}\right)$ including tetrodotoxin (TTX)-sensitive $\mathrm{Na}_{\mathrm{v}}$ channels $\left(\mathrm{TTX}-\mathrm{s} \mathrm{Na}_{\mathrm{V}}\right.$ ) and the TTX-resistant $\mathrm{Na}_{\mathrm{v}}$ channels (TTX-r $\mathrm{Na}_{\mathrm{v}}$ ) [18-21], which are largely expressed in sensory nerves [22]. PbTx binding causes conformational changes of the channel, shift in the activation voltage and impairment of inactivation. This, in turn, increases sodium entrance, leading to membrane cell hyperexcitability and subsequently to sensory disturbances [23]. Structural and functional analogs of PbTxs, called ciguatoxins (CTXs), compete with PbTxs for site 5 and cause similar modifications of channel gating [21,23]. They induce a syndrome called ciguatera fish poisoning (CFP), similar to NSP initially described by McFarren et al. [24]. In a previous study, our team showed that Pacific-ciguatoxin-2 (P-CTX-2) is able to induce the release of neuropeptides including substance $\mathrm{P}(\mathrm{SP})$ and calcitonin gene-related peptide (CGRP) in a co-culture model of human keratinocytes and rat sensory neurons [25]. Those neuropeptides and particularly SP play a major role in pruritus [26], nociception, pain [27] and lead to neurogenic inflammation $[26,28]$. A second study demonstrated that P-CTX-2-induced SP release and increase of intracellular calcium concentration $\left(\left[\mathrm{Ca}^{2+}\right]_{\mathrm{i}}\right)$ in sensory neurons. Those effects are mediated by the increase of the protease cathepsin S (Cat-S) activity and the activation of the protease-activated receptor 2 (PAR2) in a $\mathrm{Na}_{\mathrm{v}}$-dependent manner [29]. The involvement of these mediators in the pathophysiology of PbTx-induced sensory effects has never been studied.

PAR2 belongs to a family of four cell surface receptors coupled to G protein (PAR1 to PAR4). This receptor is highly expressed in the membrane of sensory neurons (around 60\%) particularly in neurons of small and medium diameter [26], as well as in keratinocytes [30]. PAR2 activation can mediate pruritus [28] and pain [31,32]. PAR2 is activated by several endogenous proteases including Cat-S mainly released from macrophages/microglia [33,34], elastase produced from neutrophils [35], trypsin from pancreas [36] and tryptase from mast cells [30]. PAR2 activation in primary sensory neurons triggers neuropeptide release, such as SP and CGRP, leading to neurogenic inflammation in the peripheral nervous system [26]. In total, $40 \%$ of dorsal root ganglion (DRG) neurons co-express CGRP and PAR2 whereas $30 \%$ of DRG neurons co-express SP and PAR2 [26]. PAR2 couples to multiple G-protein subtypes including $G \alpha q, G \alpha s$, and $G \alpha 12 / 13$, promoting diverse signaling pathways. The two main modes of activation and subsequent signaling pathways are described, namely canonical [37] and biased activation $[38,39]$. 
The canonical activation of PAR2 is mediated by proteases including trypsin, a full-agonist. Trypsin cleaves PAR2 at a specific site to reveal a new N-terminal part and a tethered ligand Ser-Leu-Ile-Gly-Lys-Val (SLIGKV) in human or Ser-Leu-Ile-Gly-Arg-Leu (SLIGRL) in rat and mouse, which is able to initiate canonical signaling [40]. On the one hand, activated PAR2 couples to G $\alpha q / 11$ and activates phospholipase C (PLC). PLC hydrolyses phosphatidyl inositol-bisphosphate (PIP2) which release inositol-1,4,5-triphosphate (IP3) and diacylglycerol (DAG) from the membrane. IP3 acts on its receptor named inositol triphosphate receptor (IP3R) which leads to a prompt $\mathrm{Ca}^{2+}$ mobilization from IP3R-dependent endoplasmic reticulum stores, and activation of protein kinases A, C and D (PKA, PKC and PKD) [41-44]. This leads to the sensitization of the transient receptor potential channels (TRP) including transient receptor potential vanilloid 1 (TRPV1) $[42,45,46]$, transient receptor potential ankyrin 1 (TRPA1) [47] and transient receptor potential vanilloid 4 (TRPV4) [48] in sensory nerve fibers contributing to sensory disorders. On the other hand, full agonists signal through $\beta$-arrestin, which is associated with PAR2 internalization, and phosphorylation of extracellular signal-regulated kinases 1 and 2 (ERK1/2) [49-52]. The signalosome complex prevents ERK translocation in the nucleus and allows phosphorylation of cytosolic substrates. Next, PAR2 moves into lysosomes where it is probably degraded or recycled. Internalization of PAR2 desensitizes cells to new PAR2 challenges. Re-sensitization occurs through PAR2 re-expression at the plasma membrane by intracellular store mobilization and/or de novo synthesis of the receptor [36]. Several proteases called biased PAR2 agonists including Cat-S or neutrophil elastase cleave PAR2 at distinct sites $[34,53]$ from the canonical trypsin site, leading to a different outcome called biased signaling. Cat-S is a lysosomal enzyme, optimally active at acid and neutral $\mathrm{pH}$. Cat-S regulates the process of maturation for the class II major histocompatibility complex in antigen presenting cells [54,55]. Cat-S elicits itch through PAR2 activation [56]. The Cat-S cleavage leads to the G $\alpha$ s-dependent formation of cyclic adenosine monophosphate (cAMP) and activation of PKA. This process, in turn, sensitizes TRP channels (e.g., TRPV4 facilitating calcium entry) and contributing to inflammatory pain $[53,57]$. Biased PAR2 agonists including Cat-S also signal through PKD and G $\beta \gamma$ to induce pain [58]. In contrast to classical PAR2 agonists, they do not signal through the $\beta$-arrestin pathway and do not internalize PAR2 [53]. Biased PAR2 agonists do not signal through G $\alpha q$ and calcium mobilization from internal stores [53,58]. However, in the cell line Hela transfected with PAR2 and human epidermal keratinocytes, Cat-S was able to induce $\left[\mathrm{Ca}^{2+}\right]_{\mathrm{i}}$ increase, generate inositol monophosphate (a downstream metabolite of IP3) and activate PKC [34]. In contrast to neutrophil elastase, Cat-S was able to couple PAR2 to G $\alpha$ q, although at higher concentrations than those required to couple PAR2 to G $\alpha$ s [58]. These data suggest that the biased PAR2 signaling induced by Cat-S could include some actors of the classical PAR2 signaling.

Downstream signaling pathways of PAR2 activation by PbTxs are unknown. Since PbTxs are structural and functional analogs of CTXs, PbTx-1 and P-CTX-2 were tested in our study. Our hypotheses were (i) PbTx-1-induces an increase of $\left[\mathrm{Ca}^{2+}\right]_{i}$ and SP release in sensory neurons; (ii) $\mathrm{Na}_{\mathrm{v}}$, PAR2 and Cat-S are involved in those effects and (iii) Actors of PAR2 downstream pathways (e.g., PKC, IP3R, PKA and TRPV4) are involved downstream of PAR2 activation induced by PbTx-1 in sensory neurons.

We performed single cell cytosolic calcium video imaging and immunocytochemical experiments on DRG sensory neurons whereas experiments of SP release were conducted with an optimized co-culture model of rat DRG neurons and human epidermal keratinocytes. In the skin, neuropeptides are released by free intra-epidermal nerve endings that are in close proximity to keratinocytes [59]. In previous work, we reported that P-CTX-2 is able to increase a SP release from sensory neurons but not from keratinocytes [29]. However, levels of SP released by DRG sensory neurons were inadequate to study the molecular actors. In contrast, levels of P-CTX-2-induced SP released by a co-culture of DRG sensory neurons and keratinocytes were six-fold higher than in DRG sensory neurons alone, becoming sufficient to study the molecular actors. This optimized model allows us to decipher the mechanisms of PbTx-1-induced SP release. 


\section{Materials and Methods}

\subsection{Primary Cell Cultures}

All experiments were approved by local authorities and in accordance with the French Ministry of Agriculture and the European Communities Council Directive 2010/63/UE. Human experiments and sample collections had local authorization, referenced under DC 2008-214 at the "Ministere de la Recherche" in France and were conducted following the principles of the Declaration of Helsinki.

Rat sensory neurons were obtained from DRG of neonatal rats as previously described [25]. Briefly, DRG were extracted from newborn Wistar rats between 3 and 5 days after birth, then enzymatically (collagenase IV, 200 units/mL) and mechanically dissociated. DRG suspension was filtered through $100 \mu \mathrm{m}$ cell strainer before seeding in 96-well plates or on glass coverslips coated with poly-L-lysine (PLL).

Human skin samples were obtained from healthy adult donors undergoing plastic surgery. The donors had given their written after informed consent. Dissociated human epidermal keratinocytes were obtained as previously described [60] with minor modification including the dispase $(20 \mathrm{UI} / \mathrm{mL})$ used for enzymatic digestion overnight at $4{ }^{\circ} \mathrm{C}$. Keratinocytes between 2 and 5 passages were maintained in complete Keratinocyte-Serum Free Medium (KSFM) for $24 \mathrm{~h}$ and then, differentiated for 14-16 h in mixture of Dulbecco's Modified Eagle Medium (DMEM) and DMEM plus Ham's F12 media (DMEM-F12) (DMEM-DMEM/F12) (1:1).

The co-culture model was performed as previously described [25] with minor modifications. Briefly, DRG neurons were seeded at a rate of one newborn rat for 10 or 12 wells in 96-well plates in DMEM/DMEM/F12 (1:1) supplemented with Normocin ${ }^{\circledR}(100 \mu \mathrm{g} / \mathrm{mL})$, B27 $(20 \mu \mathrm{L} / \mathrm{mL})$, nerve growth factor (NGF) (100 ng/mL), insulin $(4 \mu \mathrm{g} / \mathrm{mL})$, brain-derived neurotrophic factor (BDNF) $(20 \mathrm{ng} / \mathrm{mL})$ and hydrocortison (10 ng/mL). After 3-5 days of culture, the medium was removed, and 20,000 human non-differentiated keratinocytes per well were seeded in complete KSFM. Co-cultures were maintained for $24 \mathrm{~h}$ at $37^{\circ} \mathrm{C}$ in a $5 \% \mathrm{CO}_{2}$ humidified atmosphere to allow keratinocyte attachment and then, the medium was replaced by DMEM: DMEM/F12 (1:1) to induce keratinocyte differentiation for $14-16 \mathrm{~h}$.

\subsection{Single Cell Cytosolic Calcium Video Imaging}

DRG neurons were cultured on glass coverslips coated with PLL and maintained at $37^{\circ} \mathrm{C}$. Then, 1 day after, DRG neurons were placed in a recording buffer $(135 \mathrm{mM} \mathrm{NaCl}, 5 \mathrm{mM} \mathrm{KCl}, 1 \mathrm{mM} \mathrm{MgCl}$, $1.8 \mathrm{mM} \mathrm{CaCl}$, $10 \mathrm{mM}$ HEPES, $10 \mathrm{mM}$ glucose and $\mathrm{pH}$ adjusted at 7.45 with $\mathrm{NaOH}$ ) and loaded with $4 \mu \mathrm{M}$ of Fura-2/AM (Molecular Probes, Invitrogen, Cergy Pontoise, France) for $30 \mathrm{~min}$ at $37^{\circ} \mathrm{C}$. After washing, ratiometric images of calcium signals $(340 / 380 \mathrm{~nm})$ were obtained with the microscope IX71 Olympus equipped with a monochromator illumination system (Polychrome V, TILL Photonics). Emission was captured through a 415 DCLP dichroic mirror, by a 14-bit CCD camera (EXiBlue, Qimaging). Image acquisition and analysis were performed with the Metafluor 6.3 software (Universal Imaging, West Chester, PA, USA) at room temperature (RT).

At least 50 to 150 regions of interest were carefully defined with single neuron for each condition of each experiment. Each antagonist (listed in supplementary materials-Table S1) was added 10 min before image acquisition, then PbTx-1 was injected manually and data were recorded for 25 min. Only one challenge per coverslip was made (i.e., one antagonist pretreatment before one PbTx-1 treatment). Background subtraction and calculation of the resulting 340/380 ratio images were performed offline $(\Delta \mathrm{F} / \mathrm{F} 0)$ (i.e., with the formula $\Delta \mathrm{F} / \mathrm{F} 0=(\mathrm{F}-\mathrm{F} 0) / \mathrm{F} 0) . \mathrm{Ca}^{2+}$ entry was quantified after value normalization $(\Delta \mathrm{F} / \mathrm{F} 0)$ with the exception of basal $\mathrm{Ca}^{2+}$ concentrations estimated as the average of initial F340 nm/F380 nm values.

Cells were considered to respond when they exhibited a $\Delta \mathrm{F} / \mathrm{F} 0$ increase of at least 0.15 . For the responding cells, $\Delta \mathrm{F} / \mathrm{F} 0$ amplitude values for each phase of the $\mathrm{PbTx}$-1-elicited $\left[\mathrm{Ca}^{2+}\right]_{\mathrm{i}}$ increase were reported, using maximum $\Delta \mathrm{F} / \mathrm{F} 0$ for the first and the second calcium transients and the average $\Delta \mathrm{F} / \mathrm{F} 0$ 
obtained between 20 and 25 min following PbTx-1 application for the long-lasting phase also called plateau. For each phase, the inhibitory effects of antagonists were assessed first, on their ability to decrease percentages of cell responding to $\mathrm{PbTx}-1$ and secondly, the associated amplitude values using normalized data, considering as $100 \%$ the average data obtained with $\mathrm{PbTx}-1$ alone (control condition). Normalization to the control condition ( $\mathrm{PbTx}-1$ alone) was thus applied experiment by experiment which resulted in a $100 \%$ value for the PbTx-1 condition without $\mathrm{SEM}$. The " $n$ " represented the number of independent experiments in which 50 to 150 neuronal cells have been integrated to the calcium analysis.

\subsection{SP Enzyme Immunoassay (EIA)}

Levels of SP in co-culture supernatants were quantified using SP EIA Kit (R\&D systems, Minneapolis, MN, USA), according to the manufacturer's instructions and were expressed in $\mathrm{pg} / \mathrm{mL}$. Each experiment was performed in duplicate. The values from the control conditions were subtracted from those obtained under the different PbTx conditions. The average levels of released SP (in $\mathrm{pg} / \mathrm{mL}$ ) obtained under the different antagonist conditions (listed in supplementary materials-Table S1) were normalized to the average data obtained for PbTx-1 alone. The SP measurement data were expressed as mean \pm standard error of the mean (SEM) of at least three separate experiments.

\subsection{Immunocytochemical Quantification of PAR2 Internalization}

DRG neurons plated on 96-well plates were maintained in culture for 1 day. Neurons were treated with $10 \mathrm{nM}$ of P-CTX-2 for $20 \mathrm{~min}$ with or without pre-treatment of $10 \mathrm{nM}$ of Z-FL-COCHO. Cells were then fixed in paraformaldehyde $2 \%$ and were not permeabilized in order to quantify the membrane PAR2 expression. Unspecific sites were blocked in PBS-milk 5\%. PAR2 immunolabeling was performed using the mouse monoclonal [SAM11] primary antibody (Ab184673, Abcam, Paris, France, 1:100) and an anti-mouse secondary antibody coupled to horseradish peroxidase (HRP) (Jackson Immuno Research Europe, Suffolk, England). HRP substrate was added and the reaction was allowed to proceed for $20 \mathrm{~min}$. The relative levels of membrane PAR2 expression were obtained by measuring the absorbance levels at $492 \mathrm{~nm}$, which were normalized to the total amount of cells via Janus Green whole-cell staining. Each experiment was performed in triplicate. Data were expressed as mean \pm standard error of the mean (SEM) of at least three separate experiments.

\subsection{Statistical Analysis}

The statistical analyses were conducted with GraphPad Prism 6.0 (San Diego, CA, USA). The details are provided in the figure captions. Shapiro-Wilk normality test was performed and in case of non-normal distribution, a non-parametric approach was chosen. The differences were considered statistically significant with $p<0.05$.

\section{Results}

\subsection{PbTx-1-Induces an Increase of $\left[\mathrm{Ca}^{2+}{ }_{i}\right.$ in DRG Sensory Neurons}

$\mathrm{PbTx}-1$ induced $\left[\mathrm{Ca}^{2+}\right]_{\mathrm{i}}$ increase in $54 \%$ of DRG neurons. In $60 \%$ of responding neurons, the response was a remarkable multiphasic and long-lasting $\left[\mathrm{Ca}^{2+}\right]_{\mathrm{i}}$ increase (Figure 1). Immediately post injection of $1 \mu \mathrm{M}$ of $\mathrm{PbTx}-1,\left[\mathrm{Ca}^{2+}\right]_{\mathrm{i}}$ strongly increased, reaching an average maximum amplitude of $1.196 \pm 0.51$ (mean $\pm \mathrm{SD} ; n=44$ ). This first transient, called 1st peak, was rapidly down-regulated. The second transient, called 2nd peak, reached progressively an averaged maximum amplitude of $1.256 \pm 0.53$ (mean $\pm \mathrm{SD} ; n=44$ ) and continued in a long-lasting phase named plateau, which achieved an averaged amplitude of $0.492 \pm 0.49$ (mean \pm SD; $n=44$ ). In $40 \%$ of responding sensory neurons, $\mathrm{PbTx}-1$ induced a monophasic $\left[\mathrm{Ca}^{2+}\right]_{\mathrm{i}}$ increase finishing by a long-lasting phase (also called plateau). The vehicle control (medium) did not induce a calcium response. 


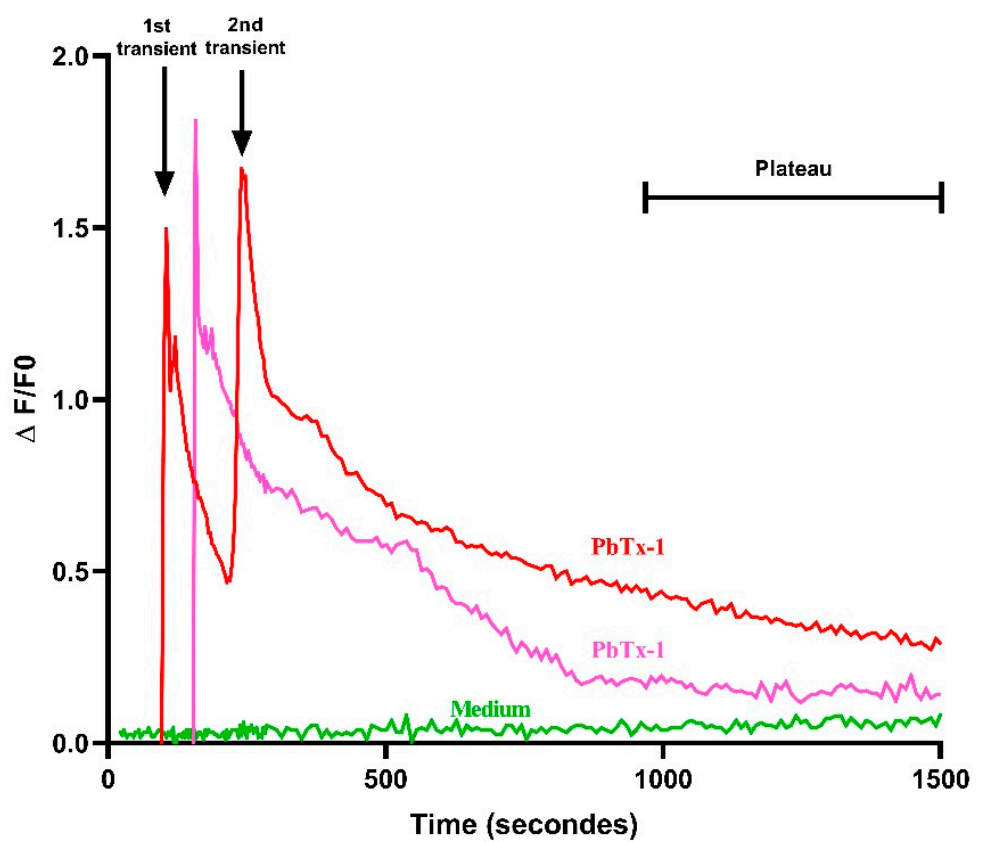

Figure 1. Representative profiles of PbTx-1-induced $\left[\mathrm{Ca}^{2+}\right]_{i}$ increase in DRG sensory neurons highlighting different subpopulations of sensory neurons. Profiles in red and pink represent $\mathrm{PbTx}-1$-induced $\left[\mathrm{Ca}^{2+}\right]_{\mathrm{i}}$ increase comprising of three phases (first transient, second transient and plateau) and two phases (transient and plateau), respectively. Medium (control) did not induce $\left[\mathrm{Ca}^{2+}\right]_{\mathrm{i}}$ increase as represented in the green line. $\left[\mathrm{Ca}^{2+}\right]_{\mathrm{i}}$ : intracellular calcium concentration; PbTx-1: brevetoxin- 1 .

3.2. PbTx-1-Induced $\left[\mathrm{Ca}^{2+}\right]_{i}$ Increase and SP Release in DRG Neurons Are Mediated by $\mathrm{Na}_{v}$ Channels, Cat-S and PAR2

To study whether $\mathrm{Na}_{\mathrm{v}}$ channels (TTX-s and TTX-r), Cat-S and PAR2 were involved in the neuronal $\left[\mathrm{Ca}^{2+}\right]_{\mathrm{i}}$ increase to PbTx1, we used TTX at $300 \mathrm{nM}$ and $100 \mu \mathrm{M}$ [61], Z-FL-COCHO $10 \mathrm{nM}$ and GB83 $5 \mu \mathrm{M}$ [62], respectively. Effect of each antagonist were assessed separately on the PbTx-1-induced $\left[\mathrm{Ca}^{2+}\right]_{\mathrm{i}}$ increase. A total of two parameters were recorded for each phase: (1) the percentage of responding cells to $\mathrm{PbTx}-1$ and (2) the associated amplitude of the response. Both parameters were normalized to those obtained without antagonist pretreatment (i.e., PbTx-1 alone). Figure 2A,C,E represent the normalized percentage of responding cells of the first and second transients and the plateau respectively. Figure 2B,D,F show the associated normalized amplitude values of each phases.

TTX $300 \mathrm{nM}$ (targeting the TTX-s Na ${ }_{\mathrm{v}}$ ) and TTX $100 \mu \mathrm{M}$ (targeting the TTX-s $\mathrm{Na}_{\mathrm{v}}$ and the TTX-r $\mathrm{Na}_{\mathrm{v}}$ channels) significantly decreased the percentage of cells responding to PbTx-1 with the first transient $(62.20 \pm 12.5 \% ; 30.5 \pm 6.4 \%$; of cells responding compared to PbTx-1 alone (100\%), respectively). The decrease of percentage of responding cells with the second transient was more pronounced by TTX $100 \mu \mathrm{M}$ than by TTX $300 \mathrm{nM}(28.2 \pm 5.4 \% ; 1.7 \pm 1.7 \%$ of cells responding compared to PbTx-1 alone $(100 \%)$, respectively). The percentage of responding cells with a plateau was slightly diminished by $300 \mathrm{nM}$ of TTX and strongly diminished by $100 \mu \mathrm{M}$ of TTX $(74.8 \pm 6.4 \% ; 12.4 \pm 3.9 \%$ of cells responding compared to PbTx-1 alone (100\%), respectively) (Figure 2A,C,E). In addition, TTX $100 \mu \mathrm{M}$ strongly decreased the amplitude of the second transient (amplitude reduced to $2.0 \pm 2.9 \%$ of that of PbTx-1 alone (100\%)), whereas $300 \mathrm{nM}$ of TTX did not (Figure 2D). We compared the effects between TTX $300 \mathrm{nM}$ versus TTX $100 \mu \mathrm{M}$; a significant difference was recorded for both percentages of responding cells and associated amplitude values of each phase, except for the amplitude values of the plateau suggesting the involvement of TTX-r $\mathrm{Na}_{\mathrm{v}}$, in addition of TTX-s $\mathrm{Na}_{\mathrm{v}}$, in $\left[\mathrm{Ca}^{2+}\right]_{i}$ induced by PbTx-1. 

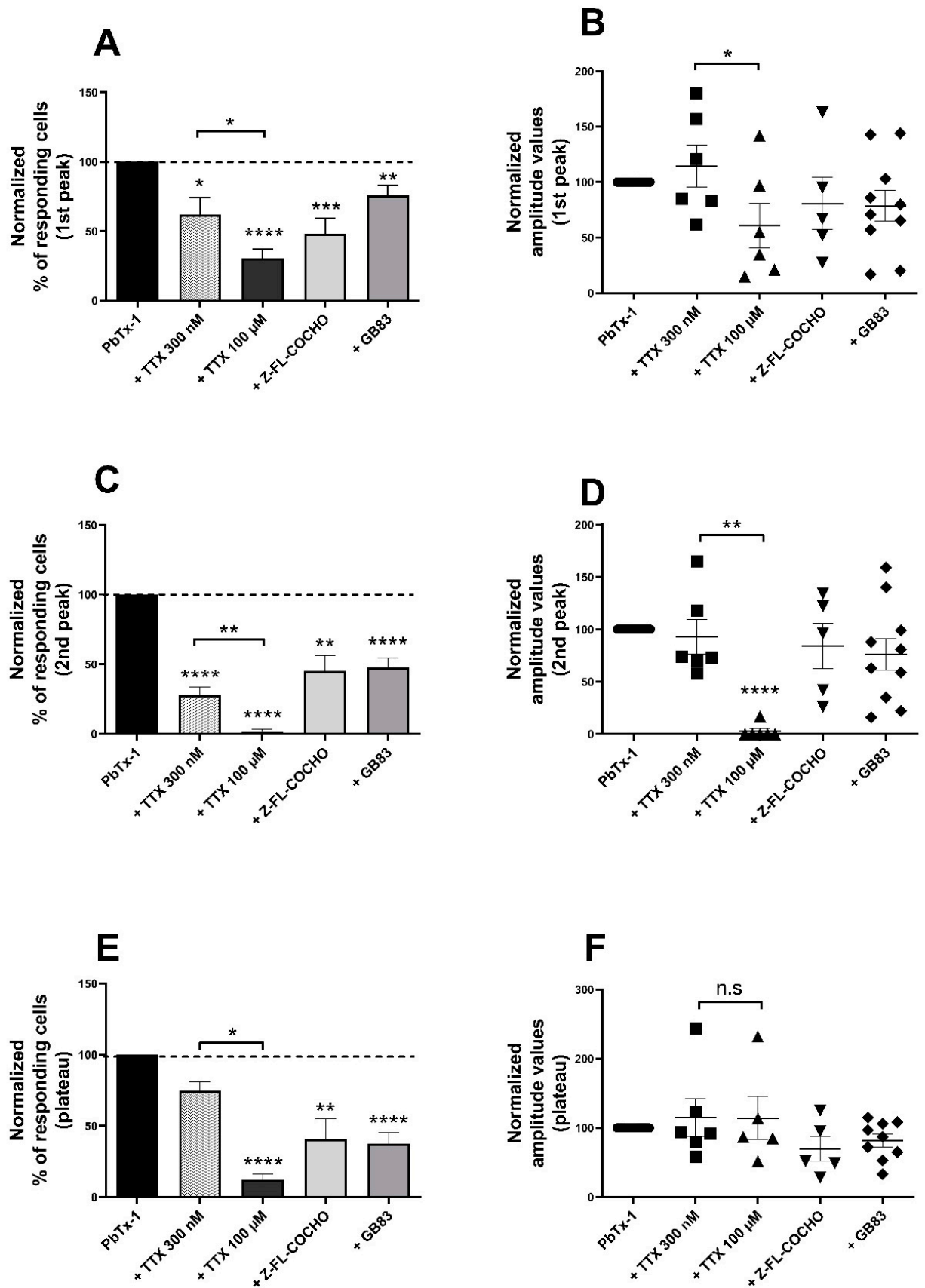

Figure 2. $\mathrm{Na}_{\mathrm{v}}$ channels (TTX-s and TTX-r), Cat-S and PAR2 mediate PbTx-1-induced $\left[\mathrm{Ca}^{2+}\right]_{\mathrm{i}}$ increase in sensory neurons. Normalized percentages of responding cells and normalized average amplitude values were recorded for the first transient $(\mathbf{A}, \mathbf{B})$, the second transient $(\mathbf{C}, \mathbf{D})$, and the plateau $(\mathbf{E}, \mathbf{F})$ in response to $1 \mu \mathrm{M}$ of $\mathrm{PbTx}-1$ alone (control condition, considered $100 \%, n=15$ ) or with pre-treatment with $300 \mathrm{nM}$ of TTX $(n=6), 100 \mu \mathrm{M}$ of TTX $(n=6), 10 \mathrm{nM}$ of Z-FL-COCHO $(n=9)$ and $5 \mu \mathrm{M}$ of GB83 $(n=9)$, expressed as mean \pm SEM. The " $n$ " represents the number of experiments in which 50 to 150 neuronal cells were included in the analysis. In the right panel, each symbol represents the normalized mean of the maximal amplitude values from the responding neurons obtained in each experiment. Statistical analysis was performed with a Kruskal-Wallis followed by Dunn's test for multiple comparisons between control and each condition, and Mann-Whitney between the condition pre-treatment with TTX $300 \mathrm{nM}$ and the condition pre-treatment with TTX $100 \mu \mathrm{M} .{ }^{*} p<0.05,{ }^{* *} p<0.01$, ${ }^{* * *} p<0.001$ and ${ }^{* * *} p<0.0001$. [ $\left[\mathrm{Ca}^{2+}\right]_{\mathrm{i}}$ : intracellular calcium concentration; Cat-S: cathepsin S; $\mathrm{Na}_{\mathrm{v}}$ : voltage-gated sodium channel; ns: non-significant; PAR2: protease-activated receptor 2; PbTx-1: brevetoxin-1; TTX: tetrodotoxin; TTX-r: TTX-resistant; TTX-s: TTX-sensitive. 
We tested the involvement of PAR2 and its agonist Cat-S in order to determine if they were also involved in $\left[\mathrm{Ca}^{2+}\right]_{\mathrm{i}}$ induced by PbTx-1. Z-FL-COCHO and GB83 significantly decreased the percentage of cells responding to PbTx-1 with the first transient (48 $\pm 11.1 \%$; $76 \pm 7.4 \%$ of responding cells compared to PbTx-1 alone $(100 \%))$, with the second transient $(45.2 \pm 11.1 \% ; 48.9 \pm 7.4 \%$ of responding cells compared to PbTx-1 alone $(100 \%))$ and the plateau $(41 \pm 13.8 \% ; 38 \pm 7.7 \%$ of responding cells compared to PbTx-1 alone (100\%)) (Figure 2A,C,E, respectively). Z-FL-COCHO and GB83 did not significantly modify the amplitude values of responding cells of each phase (Figure 2B,D,F). Together, these data suggest the critical role of $\mathrm{Na}_{\mathrm{v}}$ channels including TTX-s and TTX-r Na $\mathrm{v}_{\mathrm{v}}$, Cat-S and PAR2 in the $\mathrm{PbT} x-1$ signaling pathway in sensory neurons.

\subsection{PbTx-1 Induced Cat-S- and PAR2-Dependent SP Release from Co-Cultured Sensory Neurons and Keratinocytes}

Following 90 min of treatment with increasing concentrations of PbTx-1, we assessed the ability of PbTx-1 to induce SP release (Figure 3A). No decrease of cell viability after PbTx-1 treatment at $1 \mu \mathrm{M}(99 \pm 3.4 \%$ compared to control condition (medium, considered as $100 \%)$ ) and $2 \mu \mathrm{M}(104 \pm 1.7 \%$ compared to control condition (100\%)) was elicited while $5 \mu \mathrm{M}$ induced a slight decrease $(94 \pm 2.1 \%$ compared to control condition (100\%)) of cell viability. PbTx-1 induced a significant increase in SP release in a concentration-dependent manner $(363 \pm 87.3 \%$ at $1 \mu \mathrm{M} ; 418 \pm 119 \%$ at $2 \mu \mathrm{M}$ and $465 \pm 90 \%$ at $5 \mu \mathrm{M})$. Thus, our results show that PbTx-1 induced up to 4 -fold increase of SP release from a co-culture model of sensory neurons and human keratinocytes.

To assess the involvement of PAR2 and Cat-S in the PbTx-1-induced SP release from the co-culture model, we tested the effects of the specific antagonists GB83 and Z-FL-COCHO respectively. Both antagonists significantly reduced the PbTx-1-induced SP release to $41 \pm 7.4 \%$ and to $80 \pm 4.1 \%$ (Figure 3B).

In order to know whether Cat-S was responsible for PAR2 activation in PbTx-1-induced SP release, we compared the inhibitory effect of combined GB83/Z-FL-COCHO to GB83 alone. The inhibitory effect of GB83/Z-FL-COCHO $(40 \pm 6.9 \%)$ did not significantly differ from that of GB83 alone $(45 \pm 6.9 \%)$ (Figure 3C). These data indicate that Cat-S and PAR2 belonged to the same pathway. In contrast, the inhibitory effect of GB83 alone $(40 \pm 6.8 \%)$ was significantly higher than that of Z-FL-COCHO alone $(78 \pm 3.7 \%)$ suggesting that Cat-S was not the only mediator of PbTx-1-induced PAR2 activation.

\subsection{P-CTX-2 Induced PAR2 Internalization Independtly from Cat-S in Sensory Neurons}

To asses PAR2 membrane expression, non-permabilized DRG neurons were used and exposed to P-CTX-2 with or without Z-FL-COCHO to study Cat-S involvement (Figure 4A). P-CTX-2 induced a significant decrease in the membrane expression of PAR2 (42.3 $\pm 7.9 \%$ compared to control). Pretreatment with Z-FL-COCHO $10 \mathrm{nM}$ did not prevent the decrease in the PAR2 membrane expression $(43 \% \pm 3.6 \%)$. In order to confirm in primary culture that Cat-S as a biased agonist of PAR2 is unable to internalize PAR2, we treated human keratinocytes with $500 \mathrm{nM}$ of human recombinant Cat-S, which did not modify the PAR2 membrane expression (Figure 4B). These results indicate that P-CTX-2 induced PAR2 internalization and suggest no role of Cat-S in this effect. Thus, these results suggest that Cat-S was not the only mediator of the PAR2-dependent sensory effects induced by P-CTX-2, as by PbTx-1. 


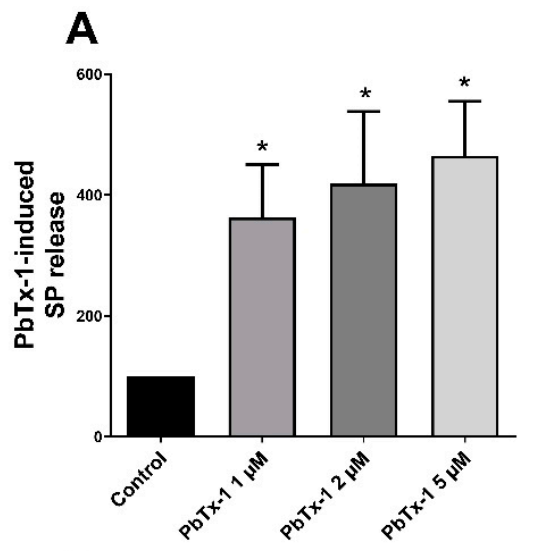

B
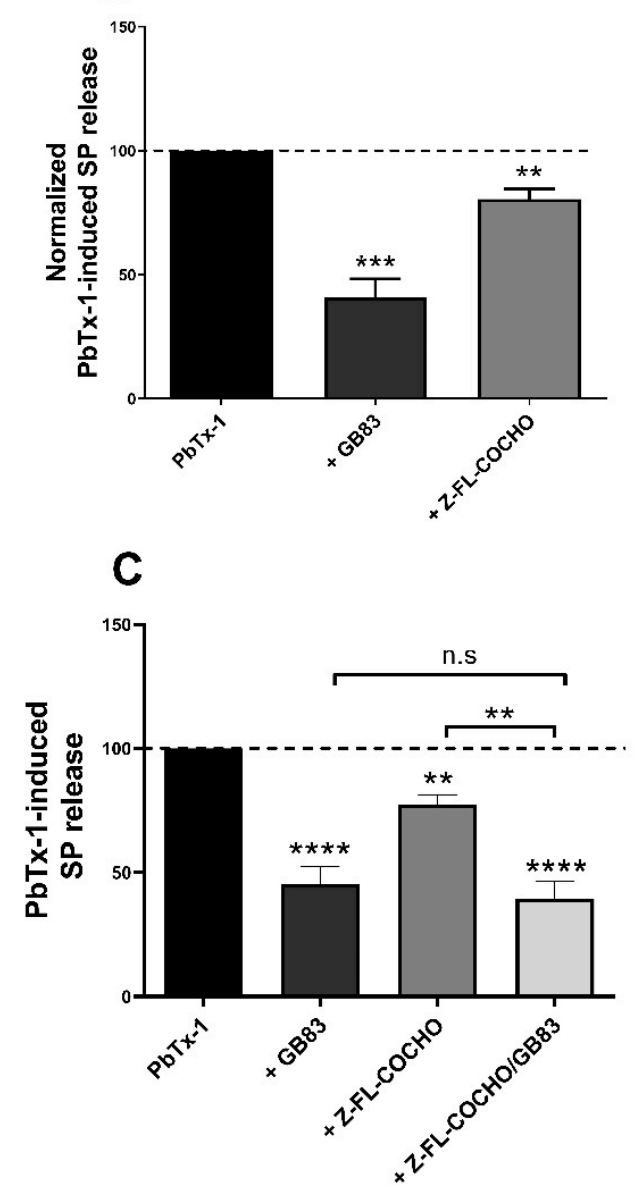

Figure 3. Effects of GB83 and Z-FL-COCHO on PbTx-1-induced SP release from co-cultured sensory neurons and keratinocytes. (A) Co-cultures were treated for 90 min with PbTx-1 $1 \mu \mathrm{M}(n=4), 2 \mu \mathrm{M}$ $(n=6)$ and $5 \mu \mathrm{M}(n=5)$. Data were normalized according to the control condition $(100 \%)$ and expressed as the mean \pm SEM and statistically analyzed with one-tailed paired t-test between $\mathrm{PbTx}-1$ condition versus control. ${ }^{*} p<0.05$. (B) GB83 and Z-FL-COCHO were pre-incubated 10 min before $1 \mu \mathrm{M} \mathrm{PbTx}-1$ for $90 \mathrm{~min}$. Normalized data were expressed as the mean \pm SEM of 7 experiments and analyzed using a one-way ANOVA followed by a Dunnet post-test for multiple comparisons to control. ${ }^{* *} p<0.01$ and *** $p<0.001$. (C) GB83, Z-FL-COCHO or the combination GB83/Z-FL-COCHO were pre-incubated $10 \mathrm{~min}$ before $1 \mu \mathrm{M}$ PbTx-1 for $90 \mathrm{~min}$. Data were expressed as the mean \pm SEM of four experiments and statistically analyzed using an one-way ANOVA followed by a Holm-Sidak test for multiple comparisons to control and between condition (GB83/Z-FL-COCHO was compared to GB83 alone and to Z-FL-COCHO alone). ${ }^{* *} p<0.01$ and ${ }^{* * *} p<0.0001$. ns: non-significant; PbTx-1: brevetoxin-1; SP: substance $P$. 

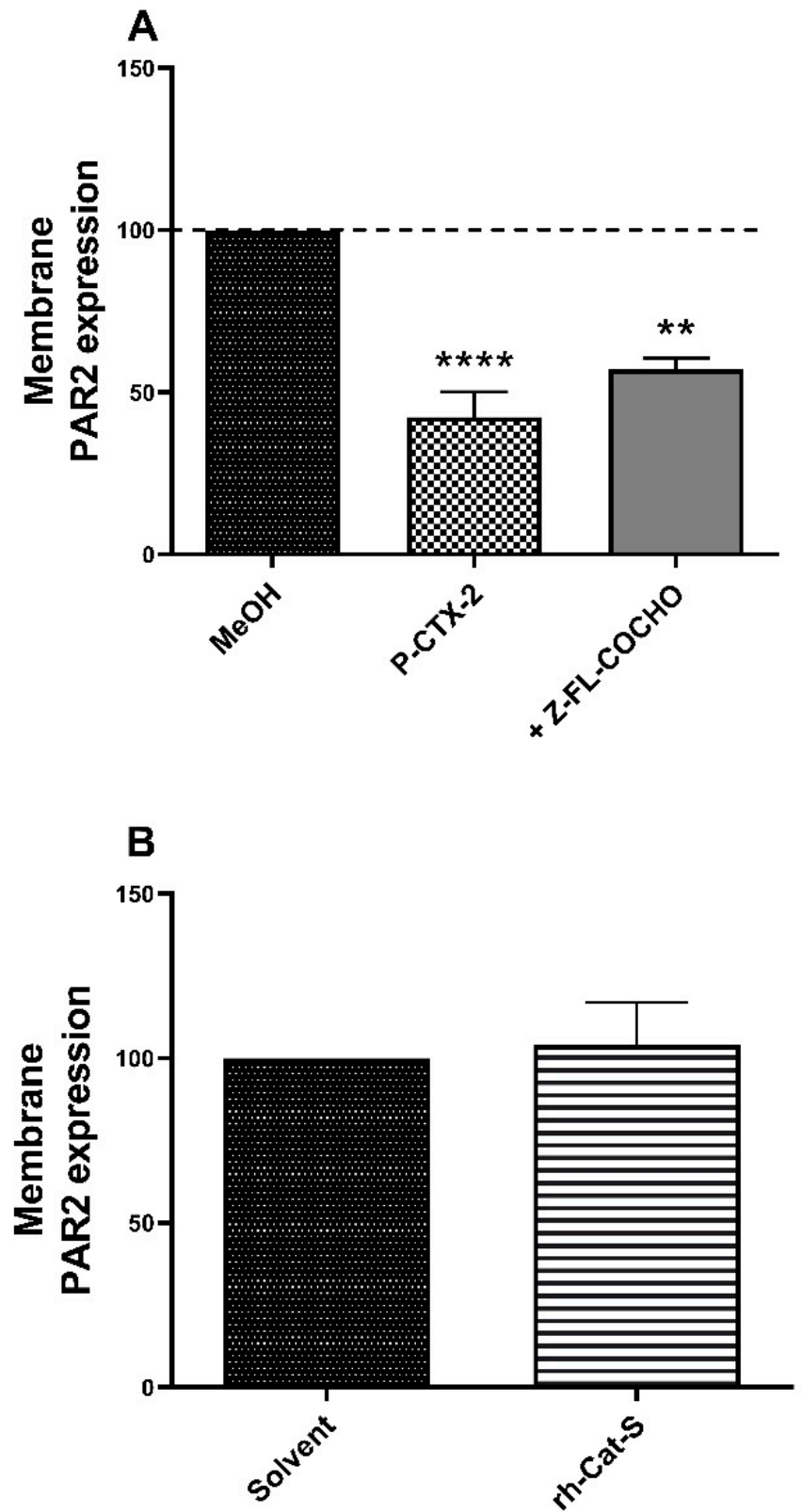

Figure 4. PAR2 internalization induced by P-CTX-2 is Cat-S-independent. (A) Effects of $10 \mathrm{nM}$ of P-CTX-2 with or without pre-treatment of $10 \mathrm{nM}$ of Z-FL-COCHO on PAR2 membrane expression in DRG neurons. Normalized data were expressed as mean \pm SEM of 3 experiments and statistically analyzed using a one-way ANOVA followed by a Holm-Sidak test for multiple comparisons to control and between P-CTX-2 and P-CTX-2/Z-FL-COCHO. ${ }^{* *} p<0.01,{ }^{* * *} p<0.0001$. (B) Effects of human recombinant Cat-S on the PAR2 membrane expression in differentiated human keratinocytes. Five hundred nM of human recombinant Cat-S were added for $20 \mathrm{~min}$. Normalized data were expressed as mean \pm SEM of two experiments. Cat-S: cathepsin S; CTX: ciguatoxin; P-CTX-2: Pacific-CTX-2; PAR2: protease-activated receptor 2; rh-Cat-S: human recombinant cathepsin S. 
3.5. PKC, PKA, IP3R and TRPV4 Are Involved in the $\left[\mathrm{Ca}^{2+}\right]_{i}$ Increase Induced by PbTx-1 in Sensory Neurons

To decipher the downstream signaling pathway of PAR2 induced by PbTx-1, we studied the involvement of PKC, PKA and IP3R in the PbTx-1-induced $\left[\mathrm{Ca}^{2+}\right]_{i}$ increase in sensory neurons. We performed single cell cytosolic calcium video imaging experiments using specific antagonists: bisindolylmaleimide X hydrochloride (BimX) for PKC [63], H89 for PKA and xestospongin C (XestC) for IP3R. None of the antagonists decreased the percentage of cells responding to PbTx-1 with the first transient (Figure 5A) however all significantly reduced the percentage of cells responding to $\mathrm{PbTx}-1$ with the second transient (to $68 \pm 6.2 \% ; 65 \pm 6.8 \% ; 62 \pm 13 \%$, compared to PbTx- 1 alone $(100 \%)$ ) (Figure 5C). In addition, H89 significantly decreased the percentage of responding cells with the plateau ( $65 \pm 6.8 \%$ compared to PbTx-1 alone, $(100 \%)$ ) (Figure $5 \mathrm{E})$. None of the antagonists significantly changed the amplitude values of the three phases of the calcium response (Figure 5B,D,F). Inhibition of PKC, PKA and IP3R prevent the $\left[\mathrm{Ca}^{2+}\right]_{i}$ increase induced by PbTx-1 in several sensory neurons (i.e., decrease the percentage of responding cells to $\mathrm{PbTx}-1$ ) but did not modify the amplitude of the response in other neuronal cells. Taken together, these results suggest the involvement of PKC and IP3R in the second transient of PbTx-1-induced $\left[\mathrm{Ca}^{2+}\right]_{i}$ increase in sensory neurons, while PKA was involved both in the second transient and the plateau.

To study the involvement of TRPV4 in the PbTx-1-induced $\left[\mathrm{Ca}^{2+}\right]_{\mathrm{i}}$ increase in sensory neurons, we used HC-067047 [63]. HC-067047 significantly reduced the PbTx-1-induced $\left[\mathrm{Ca}^{2+}\right]_{i}$ increase in the first transient (to $59 \pm 12 \%$ ), the second transient (to $36 \pm 11.5 \%$ ) and the plateau (to $35 \pm 16 \%$ ) (Figure 5A,C,E). No significant modification of amplitude values was recorded, regardless of the phase of the calcium signal (Figure $5 B, D, F)$. These results suggest the involvement of TRPV4 in the $\left[\mathrm{Ca}^{2+}\right]_{i}$ increase induced by $\mathrm{PbT}-1$.

\subsection{PKC, PKA, IP3R, and TRPV4 Are Involved in the SP Release Induced by PbTx-1 in the Co-Culture}

Based on our calcium experiment results, we explored the effects of pretreatments with PKC, PKA, IP3R and TRPV4 antagonists in the PbTx-1-induced SP release from the co-culture supernatants. $\mathrm{PbTx}-1$-induced SP release was significantly prevented by $\operatorname{BimX}$ (reduced to $37 \pm 5.9 \%$ ), H89 (reduced to $36 \pm 8.1 \%$ ), XestC (reduced to $36 \pm 9.7 \%$ ) and HC-067047 (reduced to $59 \pm 14.5 \%$ ) (Figure 6A). These findings suggest that PKC, PKA, IP3R and TRPV4 are involved in the SP release induced by $\mathrm{PbTx}-1$ from the co-culture model.

We further assessed whether TRPV4 and PAR2 belonged to the same pathway in the $\mathrm{PbTx}-1$-induced SP release. Pretreatment with a combination of GB83 and HC-067047 did not induce additional decrease in PbTx-1-induced SP release (reduced to $35 \pm 9.2 \%$ ) in conditions pre-treated with GB83 alone (reduced to $47 \pm 8.2 \%$ ) and HC-067047 alone (reduced to $41 \pm 14.5 \%$ ) (Figure 6B). This result indicates that PAR2 and TRPV4 belonged to the same signaling pathway in the PbTx-1 induced SP release and thus suggests that TRPV4 may be sensitized in a PAR2-dependent manner by PbTx-1. 

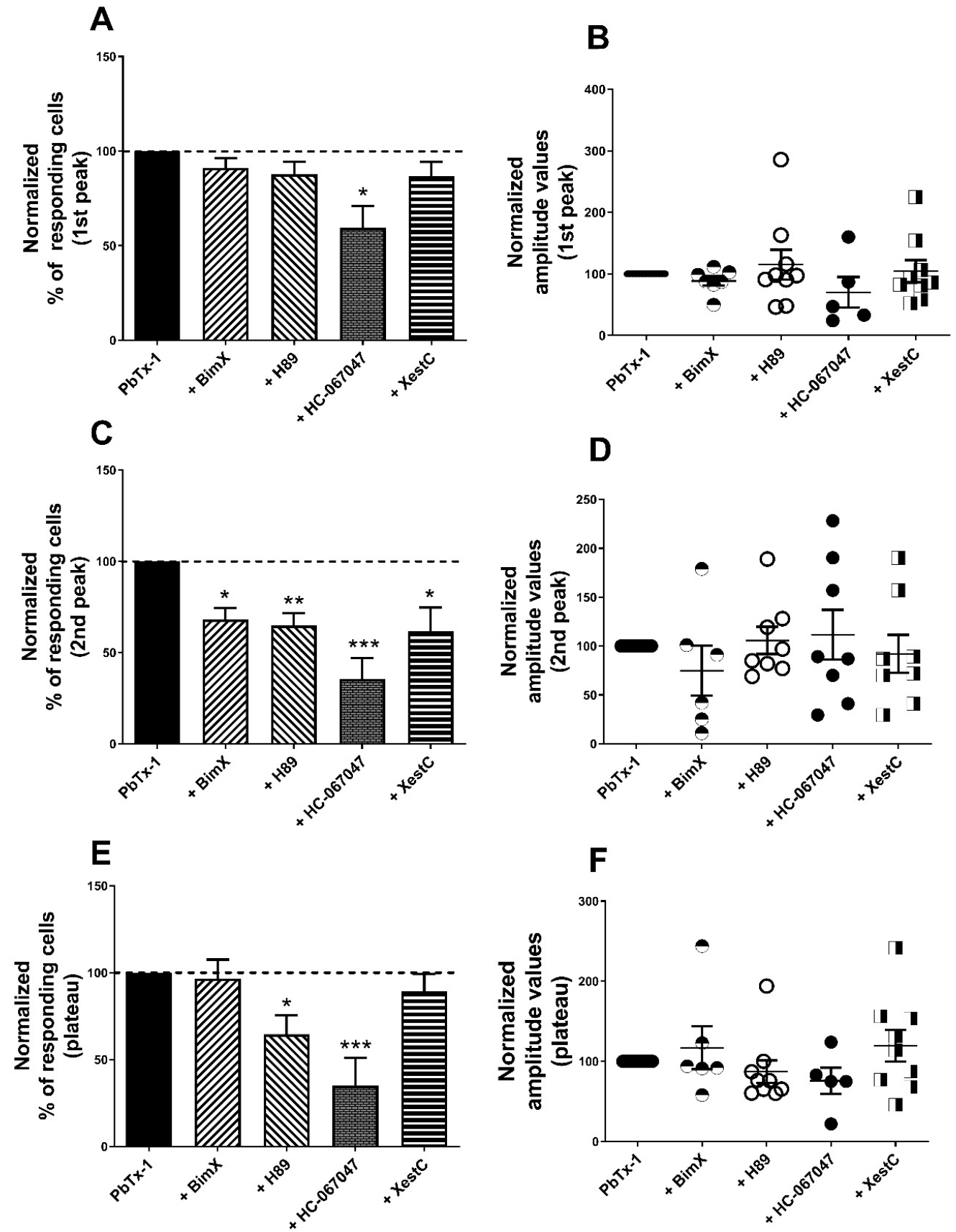

Figure 5. Effects of PKC, PKA, IP3R and TRPV4 antagonists on PbTx-1-induced $\left[\mathrm{Ca}^{2+}\right]_{i}$ increase in sensory neurons. Normalized percentages of responding cells and normalized associated amplitude values recorded for the first transient $(\mathbf{A}, \mathbf{B})$, the second transient $(\mathbf{C}, \mathbf{D})$ and the plateau $(\mathbf{E}, \mathbf{F})$ in response to $1 \mu \mathrm{M}$ of PbTx-1 alone (control condition $(100 \%), n=15)$ or with pretreatment with $10 \mu \mathrm{M}$ of $\mathrm{BimX}$ $(n=7), 5 \mu \mathrm{M}$ of H89 $(n=9), 10 \mu \mathrm{M}$ of HC-067047 $(n=5)$, and $5 \mu \mathrm{M}$ of XestC $(n=9)$ were expressed as mean \pm SEM. The " $n$ " represents the number of experiments in which 50 to 150 neuronal cells were included in the analysis. In the right panels, each symbol represents the normalized mean of the maximal amplitude values from the responding neurons obtained in each experiment. The statistical analysis was performed with performed with a Kruskal-Wallis followed by Dunn's test for multiple comparisons between control and each condition. ${ }^{*} p<0.05,{ }^{* *} p<0.01$ and ${ }^{* * *} p<0.001$. BimX: bisindolylmaleimide $\mathrm{X}$ hydrochloride; IP3R: inositol triphosphate receptor; PbTx-1: brevetoxin-1; PKA: protein kinase A; PKC: protein kinase C; TRPV4: transient receptor potential vanilloid 4; XestC: xestospongin $\mathrm{C}$. 

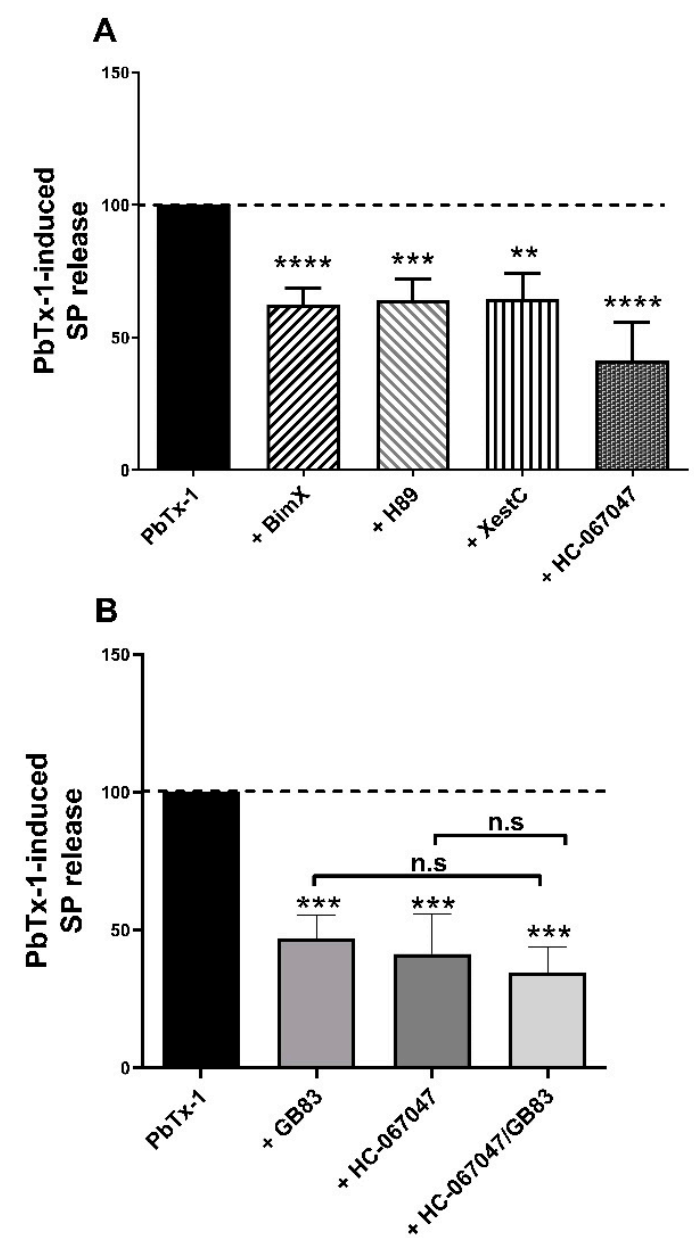

Figure 6. PbTx-1-induced SP release is mediated by PAR2 and TRPV4 in co-culture. (A) Normalized levels of SP from supernatants of co-culture in response to $1 \mu \mathrm{M}$ of PbTx- 1 alone (control condition, $n=7$ ) or with pre-treatment with $10 \mu \mathrm{M}$ of $\operatorname{BimX}(n=5)$, with $5 \mu \mathrm{M}$ of $\mathrm{H} 89(n=5)$, with $10 \mu \mathrm{M}$ of HC-067047 $(n=3)$, and with $5 \mu \mathrm{M}$ of XestC $(n=4)$ were expressed as mean \pm SEM. The data were statistically analyzed using a one-way ANOVA for multiple comparisons to control followed by a Dunnet post-test. ${ }^{* *} p<0.01,{ }^{* * *} p<0.001,{ }^{* * * *} p<0.0001$. (B) Normalized levels of SP in supernatants of co-culture in response to PbTx-1 $1 \mu \mathrm{M}$ alone (control condition, $n=3$ ) or with pre-treatment with $5 \mu \mathrm{M}$ of GB83 $(n=3)$, with $10 \mu \mathrm{M}$ of HC-067047 $(n=3)$, and with GB83/HC-067047 $(n=3)$ were expressed as mean \pm SEM. The data were analyzed using a one-way ANOVA followed by a Holm-Sidak test for multiple comparisons (GB83/HC-067047 compared to GB83 alone and HC-067047 alone). ${ }^{* * *} p<0.001$. BimX: bisindolylmaleimide $X$ hydrochloride; IP3R: inositol triphosphate receptor; ns: non-significant; PAR2: protease-activated receptor 2; PKA: protein kinase A; PKC: protein kinase C; PbTx-1: brevetoxin-1; SP: substance P; TRPV4: transient receptor potential vanilloid 4; XestC: xestospongin C.

\section{Discussion}

PbTxs induce sensory disturbances [1,2]. The objectives of this study were to (i) assess whether $\mathrm{PbTx}-1$ induces $\left[\mathrm{Ca}^{2+}\right]_{\mathrm{i}}$ increase in sensory neurons and SP release from the co-culture model; (ii) study the involvement of $\mathrm{Na}_{\mathrm{v}}$, PAR2 and Cat-S in those effects; (iii) identify signaling actors involved downstream of PAR2 activation induced by PbTx-1 in sensory neurons. We were able to demonstrate that, similarly to P-CTX-2, Cat-S and PAR2 are key actors in PbTx-1-induced $\left[\mathrm{Ca}^{2+}\right]_{i}$ increase and SP release. In addition, we demonstrated the involvement of PKC, PKA, IP3R and TRPV4 downstream of PAR2 activation induced by PbTx-1 in DRG neurons. 


\subsection{PbTx-1 Induce $\left[\mathrm{Ca}^{2+}\right]_{i}$ Increase and SP Release from Sensory Neurons and Co-Culture Model}

Different profiles of PbTx-1-induced $\left[\mathrm{Ca}^{2+}\right]_{\mathrm{i}}$ increase in sensory neurons indicate that different subpopulations of neurons were present in our culture. The PbTx-1-induced calcium response in sensory neurons showed a three phases corresponding to the three phases observed in P-CTX-2-induced calcium response in sensory neurons [29]. Almost $54 \%$ of rat sensory neurons responded to $\mathrm{PbTx}-1$ matching the proportions shown in mouse DRG neurons responding P-CTX-1B at $1 \mathrm{nM}$ [64], and in rat DRG neurons responding to $10 \mathrm{nM}$ of P-CTX-2 [29]. Notably, $1 \mu \mathrm{M}$ of PbTx-1 is a relevant concentration, given that PbTx-1 is about 500 times less potent than the P-CTX-1B and 50 times less potent than P-CTX-2 [21,65].

In the present model, $\mathrm{PbTx}-1$ at $\mu \mathrm{M}$ concentrations was able to induce a concentration dependent SP release (Figure 3A). It has been shown that CTXs at nM concentrations induced SP release from several sensory models including murine skin and DRG neurons $[25,66,67]$. Furthermore, PbTx-3 is able to induce CGRP release from motor fibers [68]. Neuropeptides including SP can be released by sensory neurons in the periphery and/or in the dorsal horn of the spinal cord [26,69] where they transmit non histaminergic pruriceptive and nociceptive information [70]. Our results suggest that SP is a key mediator of PbTx-1-induced sensory symptoms.

\subsection{Mechanisms Involved in the $\left[\mathrm{Ca}^{2+}\right]_{i}$ Increase and SP Release Induced by PbTx-1}

Sensory disturbances (e.g., paresthesia and cold dysesthesia) are likely attributable to $\mathrm{Na}_{\mathrm{v}}$ activation by PbTxs and CTXs [64,71-73]. A total of $300 \mathrm{nM}$ and $100 \mu \mathrm{M}$ TTX significantly decreased the PbTx-1 $\left[\mathrm{Ca}^{2+}\right]_{\mathrm{i}}$ increase in DRG neurons in the first transient suggesting the role of TTX-s and TTX-r $\mathrm{Na}_{\mathrm{v}}$ in the initiation of PbTx-1-induced $\left[\mathrm{Ca}^{2+}\right]_{\mathrm{i}}$ increase. Our results highlight the significantly higher involvement of TTX-r $\mathrm{Na}_{\mathrm{v}}$ compared to TTX-s $\mathrm{Na}_{\mathrm{v}}$ in the three phases of the calcium response induced by PbTx-1. TTX-r $\mathrm{Na}_{\mathrm{v}}$, including $\mathrm{Na}_{\mathrm{v}} 1.8$ and $\mathrm{Na}_{\mathrm{v}} 1.9$, particularly expressed in the peripheral nervous system [74], mediate itch and pain [75]. Our results are consistent with the role of TTX-r $\mathrm{Na}_{\mathrm{v}}$ observed with the P-CTX-2 [25], and the preferential activation of $\mathrm{Na}_{\mathrm{v}} 1.8[64,76]$ and $\mathrm{Na}_{\mathrm{v}} 1.9$ [66]. Our results suggest a critical role of TTX-r Na $\mathrm{v}_{\mathrm{v}}$ and the additional role of TTX-r $\mathrm{Na}_{\mathrm{v}}$ in the $\left[\mathrm{Ca}^{2+}\right]_{i}$ increase induced by a PbTx in sensory neurons. Wide expression of TTX-r $\mathrm{Na}_{\mathrm{v}}$, particularly in the rat DRG neurons between 2 and 5 postnatal days [77], and the additional role of TTX-r $\mathrm{Na}_{\mathrm{v}}$ in the $\left[\mathrm{Ca}^{2+}\right]_{i}$ increase induced by $\mathrm{PbTx}-1$ highlight those receptors as a potential target to treat sensory disorders.

Pretreatment with GB83 inhibited PbTx-1-induced $\left[\mathrm{Ca}^{2+}\right]_{\mathrm{i}}$ increase in sensory neurons and SP release from co-culture of sensory neurons and keratinocytes, indicating the involvement of PAR2. PAR2 is expressed by DRG sensory neurons releasing SP and CGRP [26] and by keratinocytes [30,78]. In a traumatic or inflammatory context, several proteases are released by primary afferent nerve fibers or neighboring cells. They activate PAR2, which in turn induces a $\left[\mathrm{Ca}^{2+}\right]_{i}$ increase and subsequently activates the neuropeptide release that causes neurogenic inflammation [26]. PAR2 can also sensitize TRP channels (TRPV1 [42,45,46], TRPA1 [47] and TRPV4 [48]) contributing to release neuropeptides and induces pain/pruritus. Blocking or silencing PAR2 attenuates or prevents hyperalgesia $[79,80]$. Since PAR2 is a central actor of PbTx-1 induced $\left[\mathrm{Ca}^{2+}\right]_{i}$ increase and SP release, our results highlight PAR2 as a potential target to treat sensory disorders induced by PbTxs.

As PbTxs are unlikely to exert direct protease activity, we hypothesized that PAR2 activation is indirectly induced by proteases, especially Cat-S in a Na ${ }_{\mathrm{v}}$-dependent manner $[29,81]$. Cat-S activates PAR2 in vitro [34] and induces in vivo itch, pain and inflammation in a PAR2-dependent manner $[53,56,82]$. Moreover, Cat-S plays a major role in the microglial activation and maintenance of neuropathic and chronic pain [83,84]. At a basal level, microglial cells and macrophages are the main source of Cat-S [85]. After peripheral nerve injury, Cat-S is up-regulated in DRG neurons and Schwann cells [86] as well as in keratinocytes after stimulation [87]. In addition, Cat-S and PAR2 are involved in the $\left[\mathrm{Ca}^{2+}\right]_{\mathrm{i}}$ increase and SP release induced by P-CTX-2 (i.e an analog of PbTx-1) in sensory neurons [29]. Pretreatment with Z-FL-COCHO (a Cat-S inhibitor) blocks PbTx-1-induced $\left[\mathrm{Ca}^{2+}\right]_{\mathrm{i}}$ 
increase in sensory neurons and SP release from a co-culture of sensory neurons and keratinocytes. Moreover, Cat-S activity is increased in the co-culture after treatment with P-CTX-2 and PbTx-1 [29]. Together, those data suggest that the Cat-S is involved in PbTx- signaling in DRG sensory neurons. Since Cat-S is a critical mediator involved in sensory disorders, its involvement in PbTx-1-induced SP release suggests a contribution to sensory disorders. Blocking Cat-S could represent a new therapeutic target to relieve sensory symptoms induced by $\mathrm{PbTx}-1$. Another brevetoxin analog, namely, $\mathrm{PbTx}-2$, has been previously identified as a ligand and as an inhibitor of the cysteine proteases cathepsin $\mathrm{L}$ and papain [88]. In contrast, the present study and our previous work [29] demonstrate that P-CTX-2 and $\mathrm{PbTx}-1$ increase Cat-S activity. This discrepancy could stem from the use of different toxin analogs (PbTx-2 vs. PbTx-1) and proteases (cathepsin L vs. Cat-S) or the employed methods (computational method and a protease activity assay in a cell-free model vs. direct measurement of Cat-S activity in co-culture supernatants).

\subsection{Internalization of PAR2 Induced by P-CTX-2 Is Not Mediated by Cat-S in Sensory Neurons}

At a basal level, PAR2 is mainly expressed at the cell membrane [49]. Next to canonical activation, PAR2 is internalized within a few minutes [49]. Internalization of PAR2 belongs to the canonical pathway but not the biased pathway [53]. In a previous publication using confocal microscopy and immunocytochemistry, we showed that P-CTX-2 and PbTx-1 induced a $\mathrm{Na}_{\mathrm{v}}$-dependent partial PAR2 internalization in primary keratinocytes and DRG neurons [29]. In the present study, we showed that $\left[\mathrm{Ca}^{2+}\right]_{\mathrm{i}}$ increase and SP release evoked by PbTx-1 involved the biased PAR2 agonist Cat-S. Previously Zhao et al. [53] showed that Cat-S did not internalize PAR2 in a PAR2 transfected cell line. Here, we confirmed that human recombinant Cat-S is not able to induce PAR2 internalization in differentiated primary human keratinocytes. Our results showed that pretreatment with Z-FL-COCHO did not prevent P-CTX-2 induced PAR2 internalization in sensory neurons. Thus, PAR2 internalization occurs independently from Cat-S. This suggests the involvement of other mediators, which remain to be identified, in P-CTX-2-induced PAR2 activation. Together, these results strongly suggest the implication of both biased (via Cat-S) and classical (evidenced by internalization) PAR2 pathways triggered by $\mathrm{PbTx}-1$ and P-CTX-2 in sensory neurons.

Our results imply that, in addition to Cat-S, other mediators are involved in PbTx-1-induced PAR2 activation. Kallikrein-related peptidases (KLK) are a family with, so far, 15 known members. They are expressed by the epidermal cells and appendages [89-91]. They are implicated in keratinocyte proliferation and differentiation [92] and induce itch [93,94]. Among human serine proteases, KLK5, KLK6 and KLK14 induce PAR2 signaling in human models in vitro but not KLK7 and KLK8 [91,95]. In contrast, in rat-derived KNRK transfected cells, KLK8 is not able to induce calcium signaling. This difference may be related to different methods or minor differences between species. KLK5, KLK6 and KLK14 were able to induce $\left[\mathrm{Ca}^{2+}\right]_{\mathrm{i}}$, increase comparable to trypsin $[95,96]$. Moreover, KLK14 induces PAR2 internalization and interaction between $\beta$-arrestin and PAR2 [96] indicating downstream canonical pathway involvement, comparable to trypsin [38]. Further experiments are necessary to determine the contribution of several KLKs to PAR2 activation and/or internalization in sensory neurons after PbTx-1 treatment, especially KLK5, KLK6 and KLK14

\subsection{PKC, PKA, IP3R and TRPV4 Involvement in PbTx-1-Induced $\left[\mathrm{Ca}^{2+}\right]_{i}$ Increase and SP Release}

Next we studied the role of a number of downstream actors in the canonical and biased PAR2 activation; PKC and IP3R belonging to the canonical pathway $[41,42,48]$; PKA $[42,48,97]$ and TRPV4 $[48,53]$ which are activated in both PAR2 biased and canonical pathways. PAR2 is co-expressed in DRG neurons with PKC [47], PKA [42] and TRPV4 [48]. Our results showed that both actors are implicated in $\mathrm{PbTx}-1$-induced $\left[\mathrm{Ca}^{2+}\right]_{i}$ increase in sensory neurons. Some antagonists prevent the $\left[\mathrm{Ca}^{2+}\right]_{i}$ increase induced by PbTx-1 in several sensory neurons but did not modify the amplitude of the response in other neuronal cells highlighting different subpopulations. This fact suggests the involvement of PKA, PKC and IP3R in subpopulation(s) of sensory neurons 
Results of SP release experiments conducted with BimX, H89, XestC and HC-067047 suggested the involvement of PKC, PKA, IP3R and TRPV4 in the SP release induced by PbTx-1 in our co-culture model. These results confirm the involvement of at least the canonical PAR2 signaling pathway following PAR 2 activation by PbTx-1. In addition, we identified TRPV4 as a receptor sensitized by $\mathrm{PbTx}-1$ in sensory neurons, suggesting that it could contribute to PbTx-1-induced sensory disturbances. The results highlighted in this study are summarized in Scheme 1.

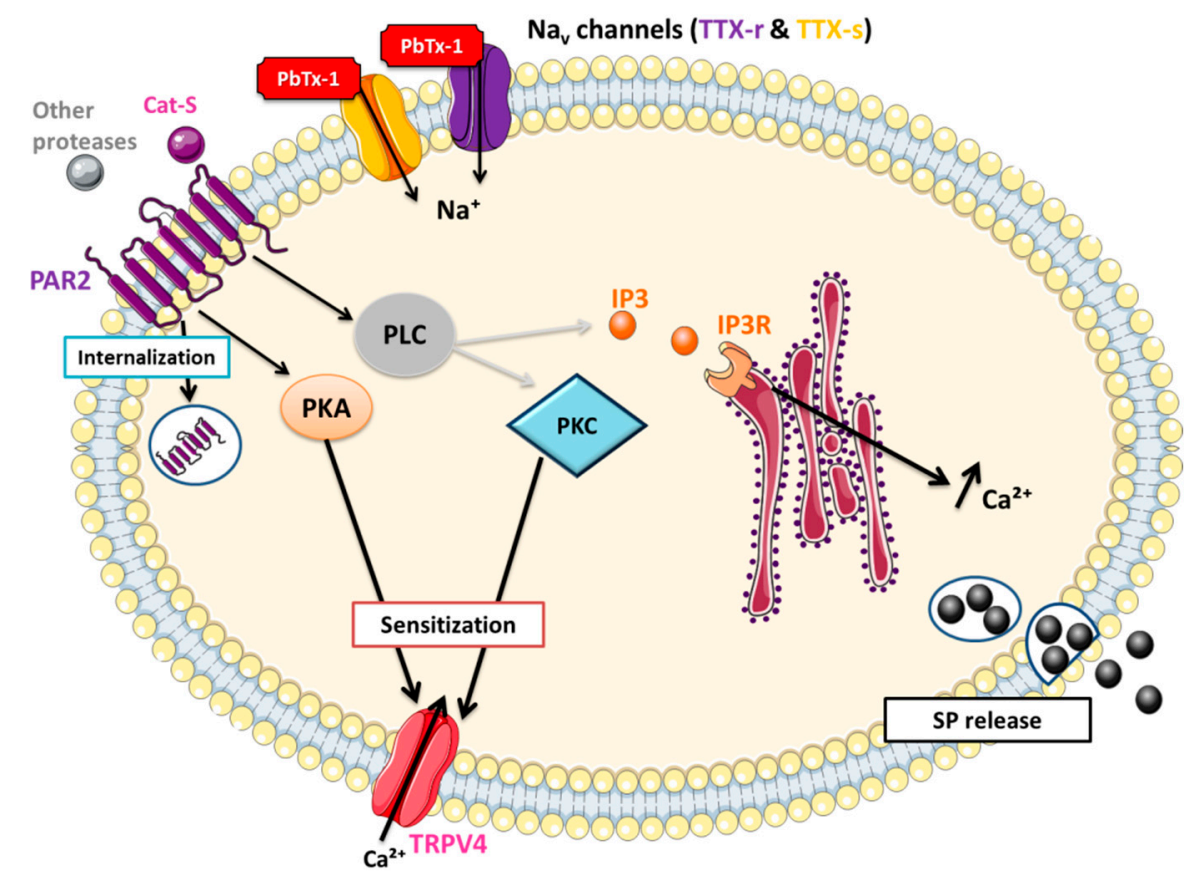

Scheme 1. Schematic representation of PbTx-1-induced signaling in sensory neurons. PbTx-1 binds $\mathrm{Na}_{\mathrm{v}}$ channels (TTX-s and TTx-r) and increases Cat-S activity (mechanisms not fully understood), which activates PAR2 and its biased pathway including PKA and TRPV4. Other mediators activate PAR2 internalization, PKC and IP3R. PAR2 activation leads to TRPV4 sensitization through PKA and/or PKC. IP3R and TRPV4 mediate $\left[\mathrm{Ca}^{2+}\right]_{\mathrm{i}}$ increase, which in turn leads to SP release. Grey arrow: not demonstrated here. $\mathrm{Ca}^{2+}$ : calcium ion; $\mathrm{Na}^{+}$: sodium ion; Cat-S: cathepsin S; IP3: inositol triphosphate; IP3R: inositol triphosphate receptor; $\mathrm{Na}_{\mathrm{v}}$ : voltage-gated sodium channel; PAR2: protease-activated receptor 2; PbTx-1: brevetoxin-1; PKA: protein kinase A; PKC: protein kinase C; PLC: phospholipase C; SP: substance P; TRPV4: transient receptor potential vanilloid 4; TTX: tetrodotoxin; TTX-r: TTX-resistant; TTX-s: TTX-sensitive.

Interestingly, IP3R were shown to be activated in myotubes of rats treated with $\mathrm{PbTx}-3$ and P-CTX-1B $[98,99]$. Our results showed their involvement in the PbTx-1-induced $\left[\mathrm{Ca}^{2+}\right]_{i}$ increase and SP release. Since we did not assess whether IP3R and PAR2 belonged to the same pathway, we cannot exclude that PAR2-independent (e.g., voltage-gated calcium channels $\left(\mathrm{Ca}_{\mathrm{V}}\right)$-dependent) mechanisms leading to IP3R activation. Further experiments are necessary to assess PAR2 dependency of IP3R involvement after $\mathrm{PbTx}-1$ treatment from sensory neurons and our co-culture model.

TRPV4 is a non-selective and permeable $\mathrm{Ca}^{2+}$ channel regulated by diverse array of stimuli such as temperature, phorbol esters (e.g., $4 \alpha$-phorbol 12,13-didecanoate), arachidonic acid, hypoosmotic swelling [100]. Calcium influx through TPRV4 can activate $\mathrm{Ca}^{2+}$-dependent PLC isoforms, and induce $\mathrm{Ca}^{2+}$ release from stores by activating IP3R or ryanodine receptors (RyR) amplifying the $\mathrm{Ca}^{2+}$ signal. $\mathrm{Ca}^{2+}$ influx through TRPV4 may contribute to the $\left[\mathrm{Ca}^{2+}\right]_{\mathrm{i}}$ increase and the SP release induced by PbTx-1. A bidirectional interaction between TRPV4 channels and IP3Rs [101] or RyR [102] is established and TRPV4 plays a central role in $\mathrm{Ca}^{2+}$ signaling [103]. Here we focused on the sensitization of TRPV4 after PAR2 activation [53]. 
Inhalation of $\mathrm{PbTx}$ aerosols induces respiratory symptoms especially in persons with underlying airway diseases such as asthma. Upper-airway symptoms include cough, sneezing, rhinorrhea, burning sensation in the nose and throat, associated with facial itch of the skin, watery eyes and neurological symptoms such as headache [9], which support that aerosolized PbTxs exert airway sensory effects. Lower-airway symptoms include chest tightness, wheezing and shortness of breath, reflecting difficulty breathing [5-8]. Interestingly, in airways, PAR2 activation leads to SP release by nerve endings, which in turn acts directly on smooth muscles to induce bronchoconstriction [104-106]. SP expression in nerve fibers is enhanced in asthmatic patients [107]. Thus, our results showing that $\mathrm{PbTx}-1$ induced a Cat-S and PAR2-dependent SP release suggest that this pathway could contribute to respiratory symptoms induced in humans after exposure to aerosolized PbTxs during red tides and be targeted to relieve these symptoms, in addition to sensory disorders.

\section{Conclusions}

Our results showed that $\mathrm{PbTx}-1$ increased $\left[\mathrm{Ca}^{2+}\right]_{i}$ in DRG neurons and SP release from coculture of DRG neurons and keratinocytes. These effects involved Cat-S and PAR2. Cat-S was not the only mediator of PAR2 activation. We decipher the signaling pathway induced by $\mathrm{PbTx}-1$, which involved PKA and TRPV4 that belong, but not exclusively, to the PAR2 biased signaling induced by Cat-S. TRPV4 activation was PAR2-dependent. We also showed that PKC and IP3R, belonging to the PAR2 canonical signaling, are involved in the PbTx-1 increased $\left[\mathrm{Ca}^{2+}\right]_{i}$ and SP release. In the context of human exposure to PbTxs through both oral and inhaled route, our findings suggest that Cat-S and even more PAR2 and TRPV4 might be interesting therapeutic targets to relieve sensory disturbances.

Supplementary Materials: The following are available online at http://www.mdpi.com/2073-4409/9/12/2704/s1, Table S1: Antagonists-their respective targets and the referenced concentrations.

Author Contributions: Conceptualization: R.L.G. and L.M.; formal analysis: O.P.; funding acquisition: R.L.G. and L.M.; investigation: O.P., M.F. and R.L.; methodology: O.P., M.F., P.B., N.L.G. and J.W.F.; project administration: R.L., R.L.G., L.M. and O.M.; supervision: R.L.G. and L.M.; validation: R.L.G. and O.M.; visualization: O.P., J.W.F. and R.L.G.; writing —original draft preparation: O.P.; writing—review and editing. All authors have read and agreed to the published version of the manuscript.

Funding: This research received no external funding.

Acknowledgments: The authors thank the French Society of Dermatology (Paris, France), the Brittany region and Celgene SARL (Paris, France) for the financial support and R.J. Lewis (Institute of Molecular Biosciences, Brisbane, Australia) for providing P-CTX-2.

Conflicts of Interest: O. Pierre, O. Mignen, L. Misery and R. Le Garrec are listed as coinventors on a pending patent assigned to the University of Brest (Universite de Bretagne Occidentale). The patent is not licensed and the authors have no conflict of interests to declare related to the subject of this publication.

\section{Abbreviations}

$\begin{array}{ll}\text { Cat-S } & \text { Cathepsin } \mathrm{S} \\ \text { CTXs } & \text { Ciguatoxins } \\ \mathrm{Na}_{\mathrm{v}} & \text { Voltage-dependent sodium channel } \\ \mathrm{NSP} & \text { Neurotoxic shellfish poisoning } \\ \text { PAR2 } & \text { Protease-activated receptor } 2 \\ \text { PbTxs } & \text { Brevetoxins } \\ \text { P-CTX-2 } & \text { Pacific-ciguatoxin-2 } \\ \text { PKA } & \text { Protein kinase A } \\ \text { PKC } & \text { Protein kinase C } \\ \text { SP } & \text { Substance P } \\ \text { TRPV4 } & \text { The transient receptor potential vanilloid 4 } \\ \text { TTX } & \text { Tetrodotoxin } \\ \text { TTX-r } \mathrm{Na}_{\mathrm{v}} & \text { Tetrodotoxin-resistant } \mathrm{Na}_{\mathrm{v}} \text { channel } \\ \text { TTX-s } \mathrm{Na}_{\mathrm{v}} & \text { Tetrodotoxin-sensitive } \mathrm{Na}_{\mathrm{v}} \text { channel }\end{array}$




\section{References}

1. Watkins, S.M.; Reich, A.; Fleming, L.E.; Hammond, R. Neurotoxic shellfish poisoning. Mar. Drugs 2008, 6, 431-455. [CrossRef]

2. Morris, P.D.; Campbell, D.S.; Taylor, T.J.; Freeman, J.I. Clinical and epidemiological features of neurotoxic shellfish poisoning in North Carolina. Am. J. Public Health 1991, 81, 471-474. [CrossRef]

3. FAO. Assessement and Management of Biotoxin Risks in Bivalve Molluscs; FAO: Rome, Italy, 2011; p. 358.

4. Kirkpatrick, B.; Fleming, L.E.; Backer, L.C.; Bean, J.A.; Tamer, R.; Kirkpatrick, G.; Kane, T.; Wanner, A.; Dalpra, D.; Reich, A.; et al. Environmental exposures to Florida red tides: Effects on emergency room respiratory diagnoses admissions. Harmful Algae 2006, 5, 526-533. [CrossRef]

5. Backer, L.C.; Fleming, L.E.; Rowan, A.; Cheng, Y.-S.; Benson, J.; Pierce, R.H.; Zaias, J.; Bean, J.; Bossart, G.D.; Johnson, D.; et al. Recreational exposure to aerosolized brevetoxins during Florida red tide events. Harmful Algae 2003, 2, 19-28. [CrossRef]

6. Backer, L.C.; Kirkpatrick, B.; Fleming, L.E.; Cheng, Y.S.; Pierce, R.; Bean, J.A.; Clark, R.; Johnson, D.; Wanner, A.; Tamer, R.; et al. Occupational Exposure to Aerosolized Brevetoxins during Florida Red Tide Events: Effects on a Healthy Worker Population. Environ. Health Perspect. 2005, 113, 644-649. [CrossRef]

7. Kirkpatrick, B.; Fleming, L.E.; Squicciarini, D.; Backer, L.C.; Clark, R.; Abraham, W.; Benson, J.; Cheng, Y.S.; Johnson, D.; Pierce, R.; et al. Literature Review of Florida Red Tide: Implications for Human Health Effects. Harmful Algae 2004, 3, 99-115. [CrossRef]

8. $\quad$ Fleming, L.E.; Kirkpatrick, B.; Backer, L.C.; Bean, J.A.; Wanner, A.; Dalpra, D.; Tamer, R.; Zaias, J.; Cheng, Y.S.; Pierce, R.; et al. Initial Evaluation of the Effects of Aerosolized Florida Red Tide Toxins (Brevetoxins) in Persons with Asthma. Environ. Health Perspect. 2005, 113, 650-657. [CrossRef]

9. Diaz, R.E.; Friedman, M.A.; Jin, D.; Beet, A.; Kirkpatrick, B.; Reich, A.; Kirkpatrick, G.; Ullmann, S.G.; Fleming, L.E.; Hoagland, P. Neurological illnesses associated with Florida red tide (Karenia brevis) blooms. Harmful Algae 2019, 82, 73-81. [CrossRef]

10. Moore, S.K.; Trainer, V.L.; Mantua, N.J.; Parker, M.S.; Laws, E.A.; Backer, L.C.; Fleming, L.E. Impacts of climate variability and future climate change on harmful algal blooms and human health. Environ. Health 2008, 7, S4. [CrossRef]

11. Turner, A.D.; Higgins, C.; Davidson, K.; Veszelovszki, A.; Payne, D.; Hungerford, J.; Higman, W. Potential Threats Posed by New or Emerging Marine Biotoxins in UK Waters and Examination of Detection Methodology Used in Their Control: Brevetoxins. Mar. Drugs 2015, 13, 1224-1254. [CrossRef]

12. Walsh, C.J.; Leggett, S.R.; Carter, B.J.; Colle, C. Effects of brevetoxin exposure on the immune system of loggerhead sea turtles. Aquat. Toxicol. 2010, 97, 293-303. [CrossRef]

13. Bossart, G.D.; Baden, D.G.; Ewing, R.Y.; Roberts, B.; Wright, S.D. Brevetoxicosis in manatees (Trichechus manatus latirostris) from the 1996 epizootic: Gross, histologic, and immunohistochemical features. Toxicol. Pathol. 1998, 26, 276-282. [CrossRef]

14. Fire, S.E.; Fauquier, D.; Flewelling, L.J.; Henry, M.; Naar, J.; Pierce, R.; Wells, R.S. Brevetoxin exposure in bottlenose dolphins (Tursiops truncatus) associated with Karenia brevis blooms in Sarasota Bay, Florida. Mar. Biol. 2007, 152, 827-834. [CrossRef]

15. Fire, S.E.; Flewelling, L.J.; Stolen, M.; Durden, W.N.; de Wit, M.; Spellman, A.C.; Wang, Z. Brevetoxin-associated mass mortality event of bottlenose dolphins and manatees along the east coast of Florida, USA. Mar. Ecol. Prog. Ser. 2015, 526, 241-251. [CrossRef]

16. Cheng, Y.S.; Zhou, Y.; Irvin, C.M.; Pierce, R.H.; Naar, J.; Backer, L.C.; Fleming, L.E.; Kirkpatrick, B.; Baden, D.G. Characterization of Marine Aerosol for Assessment of Human Exposure to Brevetoxins. Environ. Health Perspect. 2005, 113, 638-643. [CrossRef]

17. Pierce, R.H.; Henry, M.S.; Blum, P.C.; Hamel, S.L.; Kirkpatrick, B.; Cheng, Y.S.; Zhou, Y.; Irvin, C.M.; Naar, J.; Weidner, A.; et al. Brevetoxin composition in water and marine aerosol along a Florida beach: Assessing potential human exposure to marine biotoxins. Harmful Algae 2005, 4, 965-972. [CrossRef]

18. Lombet, A.; Bidard, J.N.; Lazdunski, M. Ciguatoxin and brevetoxins share a common receptor site on the neuronal voltage-dependent $\mathrm{Na}+$ channel. FEBS Lett. 1987, 219, 355-359. [CrossRef]

19. Gawley, R.E.; Rein, K.S.; Kinoshita, M.; Baden, D.G. Binding of brevetoxins and ciguatoxin to the voltage-sensitive sodium channel and conformational analysis of brevetoxin B. Toxicon 1992, 30, 780-785. [CrossRef] 
20. Whitney, P.L.; Baden, D.G. Complex association and dissociation kinetics of brevetoxin binding to voltage-sensitive rat brain sodium channels. Nat. Toxins 1996, 4, 261-270. [CrossRef]

21. Dechraoui, M.-Y.; Naar, J.; Pauillac, S.; Legrand, A.-M. Ciguatoxins and brevetoxins, neurotoxic polyether compounds active on sodium channels. Toxicon 1999, 37, 125-143. [CrossRef]

22. Wood, J.N.; Akopian, A.N.; Baker, M.; Ding, Y.; Geoghegan, F.; Nassar, M.; Malik-Hall, M.; Okuse, K.; Poon, L.; Ravenall, S.; et al. Sodium Channels in Primary Sensory Neurons: Relationship to Pain States. In Novartis Foundation Symposia; Bock, G., Goode, J.A., Eds.; John Wiley \& Sons, Ltd.: Chichester, UK, 2008; pp. 159-172. ISBN 978-0-471-48530-8.

23. Baden, D.G. Brevetoxins: Unique polyether dinoflagellate toxins. FASEB J. 1989, 3, 1807-1817. [CrossRef] [PubMed]

24. McFarren, E.F.; Tanabe, H.; Silva, F.J.; Wilson, W.B.; Campbell, J.E.; Lewis, K.H. The occurrence of a ciguatera-like poison in oysters, clams, and Gymnodinium breve cultures. Toxicon 1965, 3, 111-123. [CrossRef]

25. Le Garrec, R.; L'Herondelle, K.; Le Gall-Ianotto, C.; Lebonvallet, N.; Leschiera, R.; Buhe, V.; Talagas, M.; Vetter, I.; Lewis, R.J.; Misery, L. Release of neuropeptides from a neuro-cutaneous co-culture model: A novel in vitro model for studying sensory effects of ciguatoxins. Toxicon 2016, 116, 4-10. [CrossRef] [PubMed]

26. Steinhoff, M.; Vergnolle, N.; Young, S.H.; Tognetto, M.; Amadesi, S.; Ennes, H.S.; Trevisani, M.; Hollenberg, M.D.; Wallace, J.L.; Caughey, G.H.; et al. Agonists of proteinase-activated receptor 2 induce inflammation by a neurogenic mechanism. Nat. Med. 2000, 6, 151-158. [CrossRef]

27. Henry, J.L. Substance P and pain: An updating. Trends Neurosci. 1980, 3, 95-97. [CrossRef]

28. Vergnolle, N.; Ferazzini, M.; D’Andrea, M.R.; Buddenkotte, J.; Steinhoff, M. Proteinase-activated receptors: Novel signals for peripheral nerves. Trends Neurosci. 2003, 26, 496-500. [CrossRef]

29. L'Herondelle, K.; Pierre, O.; Fouyet, S.; Leschiera, R.; Le Gall-Ianotto, C.; Philippe, R.; Buscaglia, P.; Mignen, O.; Talagas, M.; Lewis, R.J.; et al. PAR2, keratinocytes, and cathesin S mediate the sensory effects of ciguatoxins reponsible for ciguatera poisoning. J. Investig. Dermatol. 2020, in press.

30. Steinhoff, M.; Corvera, C.U.; Thoma, M.S.; Kong, W.; McAlpine, B.E.; Caughey, G.H.; Ansel, J.C.; Bunnett, N.W. Proteinase-activated receptor-2 in human skin: Tissue distribution and activation of keratinocytes by mast cell tryptase. Exp. Dermatol. 1999, 8, 282-294. [CrossRef]

31. Vergnolle, N.; Wallace, J.L.; Bunnett, N.W.; Hollenberg, M.D. Protease-activated receptors in inflammation, neuronal signaling and pain. Trends Pharmacol. Sci. 2001, 22, 146-152. [CrossRef]

32. Bao, Y.; Hou, W.; Hua, B. Protease-activated receptor 2 signalling pathways: A role in pain processing. Expert Opin. Ther. Targets 2014, 18, 15-27. [CrossRef]

33. Clark, A.K.; Wodarski, R.; Guida, F.; Sasso, O.; Malcangio, M. Cathepsin S release from primary cultured microglia is regulated by the P2X7 receptor. Glia 2010, 58, 1710-1726. [CrossRef] [PubMed]

34. Elmariah, S.B.; Reddy, V.B.; Lerner, E.A. Cathepsin S Signals via PAR2 and Generates a Novel Tethered Ligand Receptor Agonist. PLoS ONE 2014, 9, e99702. [CrossRef] [PubMed]

35. Zhao, P.; Lieu, T.; Barlow, N.; Sostegni, S.; Haerteis, S.; Korbmacher, C.; Liedtke, W.; Jimenez-Vargas, N.N.; Vanner, S.J.; Bunnett, N.W. Neutrophil Elastase Activates Protease-activated Receptor-2 (PAR2) and Transient Receptor Potential Vanilloid 4 (TRPV4) to Cause Inflammation and Pain. J. Biol. Chem. 2015, 290, 13875-13887. [CrossRef]

36. Böhm, S.K.; Kong, W.; Bromme, D.; Smeekens, S.P.; Anderson, D.C.; Connolly, A.; Kahn, M.; Nelken, N.A.; Coughlin, S.R.; Payan, D.G.; et al. Molecular cloning, expression and potential functions of the human proteinase-activated receptor-2. Biochem. J. 1996, 314, 1009-1016. [CrossRef]

37. Jimenez-Vargas, N.N.; Pattison, L.A.; Zhao, P.; Lieu, T.; Latorre, R.; Jensen, D.D.; Castro, J.; Aurelio, L.; Le, G.T.; Flynn, B.; et al. Protease-activated receptor-2 in endosomes signals persistent pain of irritable bowel syndrome. Proc. Natl. Acad. Sci. USA 2018, 115, E7438-E7447. [CrossRef]

38. Ramachandran, R.; Mihara, K.; Chung, H.; Renaux, B.; Lau, C.S.; Muruve, D.A.; DeFea, K.A.; Bouvier, M.; Hollenberg, M.D. Neutrophil Elastase Acts as a Biased Agonist for Proteinase-activated Receptor-2 (PAR-2). J. Biol. Chem. 2011, 286, 24638-24648. [CrossRef]

39. Zhao, P.; Metcalf, M.; Bunnett, N.W. Biased Signaling of Protease-Activated Receptors. Front. Endocrinol. 2014, 5. [CrossRef] [PubMed]

40. Nystedt, S.; Emilsson, K.; Wahlestedt, C.; Sundelin, J. Molecular cloning of a potential proteinase activated receptor. Proc. Natl. Acad. Sci. USA 1994, 91, 9208-9212. [CrossRef] 
41. Böhm, S.K.; Khitin, L.M.; Grady, E.F.; Aponte, G.; Payan, D.G.; Bunnett, N.W. Mechanisms of Desensitization and Resensitization of Proteinase-activated Receptor-2. J. Biol. Chem. 1996, 271, 22003-22016. [CrossRef]

42. Amadesi, S.; Cottrell, G.S.; Divino, L.; Chapman, K.; Grady, E.F.; Bautista, F.; Karanjia, R.; Barajas-Lopez, C.; Vanner, S.; Vergnolle, N.; et al. Protease-activated receptor 2 sensitizes TRPV1 by protein kinase C $\varepsilon$ - and A-dependent mechanisms in rats and mice. J. Physiol. 2006, 575, 555-571. [CrossRef]

43. Amadesi, S.; Grant, A.D.; Cottrell, G.S.; Vaksman, N.; Poole, D.P.; Rozengurt, E.; Bunnett, N.W. Protein Kinase D Isoforms Are Expressed in Rat and Mouse Primary Sensory Neurons and Are activated by Agonists Of Protease-Activated Receptor 2. J. Comp. Neurol. 2009, 516, 141-156. [CrossRef] [PubMed]

44. Gouin, O.; L'Herondelle, K.; Buscaglia, P.; Le Gall-Ianotto, C.; Philippe, R.; Legoux, N.; Mignen, O.; Buhé, V.; Leschiera, R.; Sakka, M.; et al. Major Role for TRPV1 and InsP3R in PAR2-Elicited Inflammatory Mediator Production in Differentiated Human Keratinocytes. J. Investig. Dermatol. 2018, 138, 1564-1572. [CrossRef]

45. Amadesi, S. Protease-Activated Receptor 2 Sensitizes the Capsaicin Receptor Transient Receptor Potential Vanilloid Receptor 1 to Induce Hyperalgesia. J. Neurosci. 2004, 24, 4300-4312. [CrossRef]

46. Mrozkova, P.; Spicarova, D.; Palecek, J. Hypersensitivity Induced by Activation of Spinal Cord PAR2 Receptors Is Partially Mediated by TRPV1 Receptors. PLoS ONE 2016, 11, e0163991. [CrossRef] [PubMed]

47. Dai, Y.; Wang, S.; Tominaga, M.; Yamamoto, S.; Fukuoka, T.; Higashi, T.; Kobayashi, K.; Obata, K.; Yamanaka, H.; Noguchi, K. Sensitization of TRPA1 by PAR2 contributes to the sensation of inflammatory pain. J. Clin. Investig. 2007, 117, 1979-1987. [CrossRef]

48. Grant, A.D.; Cottrell, G.S.; Amadesi, S.; Trevisani, M.; Nicoletti, P.; Materazzi, S.; Altier, C.; Cenac, N.; Zamponi, G.W.; Bautista-Cruz, F.; et al. Protease-activated receptor 2 sensitizes the transient receptor potential vanilloid 4 ion channel to cause mechanical hyperalgesia in mice. J. Physiol. 2007, 578, 715-733. [CrossRef]

49. Déry, O.; Thoma, M.S.; Wong, H.; Grady, E.F.; Bunnett, N.W. Trafficking of proteinase-activated receptor-2 and Beta-arrestion-1 tagged with green fluorescent protein. J. Biol. Chem. 1999, 274, 18524-18535. [CrossRef]

50. DeFea, K.A.; Zalevsky, J.; Thoma, M.S.; Déry, O.; Mullins, R.D.; Bunnett, N.W. $\beta$-Arrestin-Dependent Endocytosis of Proteinase-Activated Receptor 2 Is Required for Intracellular Targeting of Activated ERK1/2. J. Cell Biol. 2000, 148, 1267-1281. [CrossRef]

51. Stalheim, L.; Ding, Y.; Gullapalli, A.; Paing, M.M.; Wolfe, B.L.; Morris, D.R.; Trejo, J. Multiple Independent Functions of Arrestins in the Regulation of Protease-Activated Receptor-2 Signaling and Trafficking. Mol. Pharmacol. 2005, 67, 78-87. [CrossRef]

52. Kumar, P.; Lau, C.S.; Mathur, M.; Wang, P.; DeFea, K.A. Differential effects of beta-arrestins on the internalization, desensitization and ERK1/2 activation downstream of protease activated receptor-2. Am. J. Physiol. Cell Physiol. 2007, 293, C346-C357. [CrossRef]

53. Zhao, P.; Lieu, T.; Barlow, N.; Metcalf, M.; Veldhuis, N.A.; Jensen, D.D.; Kocan, M.; Sostegni, S.; Haerteis, S.; Baraznenok, V.; et al. Cathepsin S Causes Inflammatory Pain via Biased Agonism of PAR2 and TRPV4. J. Biol. Chem. 2014, 289, 27215-27234. [CrossRef] [PubMed]

54. Driessen, C.; Bryant, R.A.R.; Lennon-Duménil, A.-M.; Villadangos, J.A.; Bryant, P.W.; Shi, G.-P.; Chapman, H.A.; Ploegh, H.L. Cathepsin S Controls the Trafficking and Maturation of Mhc Class II Molecules in Dendritic Cells. J. Cell Biol. 1999, 147, 775-790. [CrossRef] [PubMed]

55. Hsieh, C.-S.; deRoos, P.; Honey, K.; Beers, C.; Rudensky, A.Y. A Role for Cathepsin L and Cathepsin S in Peptide Generation for MHC Class II Presentation. J. Immunol. 2002, 168, 2618-2625. [CrossRef] [PubMed]

56. Reddy, V.B.; Shimada, S.G.; Sikand, P.; LaMotte, R.H.; Lerner, E.A. Cathepsin S elicits itch and signals via protease-activated receptors. J. Investig. Dermatol. 2010, 130, 1468-1470. [CrossRef]

57. Sostegni, S.; Diakov, A.; McIntyre, P.; Bunnett, N.; Korbmacher, C.; Haerteis, S. Sensitisation of TRPV4 by PAR2 is independent of intracellular calcium signalling and can be mediated by the biased agonist neutrophil elastase. Pflugers Arch. 2015, 467, 687-701. [CrossRef]

58. Zhao, P.; Pattison, L.A.; Jensen, D.D.; Jimenez-Vargas, N.N.; Latorre, R.; Lieu, T.; Jaramillo, J.O.; Lopez-Lopez, C.; Poole, D.P.; Vanner, S.J.; et al. Protein kinase D and G $\beta \gamma$ mediate sustained nociceptive signaling by biased agonists of protease-activated receptor-2. J. Biol. Chem. 2019, 294, 10649-10662. [CrossRef]

59. Talagas, M.; Lebonvallet, N.; Leschiera, R.; Sinquin, G.; Elies, P.; Haftek, M.; Pennec, J.-P.; Ressnikoff, D.; Padula, V.L.; Garrec, R.L.; et al. Keratinocytes Communicate with Sensory Neurons via Synaptic-like Contacts. Ann. Neurol. 2020, 88, 1205-1219. [CrossRef] 
60. Le Gall-Ianotto, C.; Andres, E.; Hurtado, S.P.; Pereira, U.; Misery, L. Characterization of the first coculture between human primary keratinocytes and the dorsal root ganglion-derived neuronal cell line F-11. Neuroscience 2012, 210, 47-57. [CrossRef]

61. Dib-Hajj, S.; Black, J.A.; Cummins, T.R.; Waxman, S.G. NaN/Nav1.9: A sodium channel with unique properties. Trends Neurosci. 2002, 25, 253-259. [CrossRef]

62. Barry, G.D.; Suen, J.Y.; Le, G.T.; Cotterell, A.; Reid, R.C.; Fairlie, D.P. Novel Agonists and Antagonists for Human Protease Activated Receptor 2. J. Med. Chem. 2010, 53, 7428-7440. [CrossRef]

63. Poole, D.P.; Amadesi, S.; Veldhuis, N.A.; Abogadie, F.C.; Lieu, T.; Darby, W.; Liedtke, W.; Lew, M.J.; McIntyre, P.; Bunnett, N.W. Protease-activated Receptor 2 (PAR-2) Protein and Transient Receptor Potential Vanilloid 4 (TRPV4) Protein Coupling Is Required for Sustained Inflammatory Signaling. J. Biol. Chem. 2013, 288, 5790-5802. [CrossRef]

64. Vetter, I.; Touska, F.; Hess, A.; Hinsbey, R.; Sattler, S.; Lampert, A.; Sergejeva, M.; Sharov, A.; Collins, L.S.; Eberhardt, M.; et al. Ciguatoxins activate specific cold pain pathways to elicit burning pain from cooling. EMBO J. 2012, 31, 3795-3808. [CrossRef]

65. Lewis, R.J.; Sellin, M.; Poli, M.A.; Norton, R.S.; MacLeod, J.K.; Sheil, M.M. Purification and characterization of ciguatoxins from moray eel (Lycodontis javanicus, Muraenidae). Toxicon 1991, 29, 1115-1127. [CrossRef]

66. Touska, F.; Sattler, S.; Malsch, P.; Lewis, R.J.; Reeh, P.W.; Zimmermann, K. Ciguatoxins Evoke Potent CGRP Release by Activation of Voltage-Gated Sodium Channel Subtypes NaV1.9, NaV1.7 and NaV1.1. Mar. Drugs 2017, 15, 269. [CrossRef]

67. Zimmermann, K.; Deuis, J.R.; Inserra, M.C.; Collins, L.S.; Namer, B.; Cabot, P.J.; Reeh, P.W.; Lewis, R.J.; Vetter, I. Analgesic treatment of ciguatoxin-induced cold allodynia. Pain 2013, 154, 1999-2006. [CrossRef]

68. Molgó, J.; Meunier, F.A.; Colasante, C.; Poulain, B. Marine Toxins Affecting Quantal Acetylcholine Release and Transmission at the Vertebrate Neuromuscular Junction. In Advances in Organ Biology; Elsevier: Amsterdam, The Netherlands, 1997; Volume 2, pp. 249-284, ISBN 978-0-7623-0222-2.

69. McCarthy, P.W.; Lawson, S.N. Cell type and conduction velocity of rat primary sensory neurons with substance p-like immunoreactivity. Neuroscience 1989, 28, 745-753. [CrossRef]

70. Steinhoff, M.; Bienenstock, J.; Schmelz, M.; Maurer, M.; Wei, E.; Bíró, T. Neurophysiological, Neuroimmunological, and Neuroendocrine Basis of Pruritus. J. Investig. Dermatol. 2006, 126, 1705-1718. [CrossRef]

71. Zimmermann, K.; Leffler, A.; Babes, A.; Cendan, C.M.; Carr, R.W.; Kobayashi, J.; Nau, C.; Wood, J.N.; Reeh, P.W. Sensory neuron sodium channel Nav1.8 is essential for pain at low temperatures. Nature 2007, 447, 856-859. [CrossRef]

72. Ramsdell, J. The Molecular and Integrative Basis to Brevetoxin Toxicity. In Seafood and Freshwater Toxins: Pharmacology, Physiology, and Detection, Second Edition; CRC Press Inc.: Boca Raton, FL, USA, 2008; pp. 519-550.

73. Inserra, M.C.; Israel, M.R.; Caldwell, A.; Castro, J.; Deuis, J.R.; Harrington, A.M.; Keramidas, A.; Garcia-Caraballo, S.; Maddern, J.; Erickson, A.; et al. Multiple sodium channel isoforms mediate the pathological effects of Pacific ciguatoxin-1. Sci. Rep. 2017, 7, 42810. [CrossRef]

74. Benn, S.C.; Costigan, M.; Tate, S.; Fitzgerald, M.; Woolf, C.J. Developmental Expression of the TTX-Resistant Voltage-Gated Sodium Channels Nav1.8 (SNS) and Nav1.9 (SNS2) in Primary Sensory Neurons. J. Neurosci. 2001, 21, 6077-6085. [CrossRef]

75. Morfey, M. A review into the role of voltage gated sodium channels 1.8 and 1.9 in pain states: And medical uses of this knowledge. Plymouth Stud. Sci. 2012, 5, 294-303.

76. Yamaoka, K.; Inoue, M.; Miyazaki, K.; Hirama, M.; Kondo, C.; Kinoshita, E.; Miyoshi, H.; Seyama, I. Synthetic Ciguatoxins Selectively Activate Nav1.8-derived Chimeric Sodium Channels Expressed in HEK293 Cells. J. Biol. Chem. 2009, 284, 7597-7605. [CrossRef] [PubMed]

77. Roy, M.L.; Narahashi, T. Differential properties of tetrodotoxin-sensitive and tetrodotoxin-resistant sodium channels in rat dorsal root ganglion neurons. J. Neurosci. 1992, 12, 2104-2111. [CrossRef] [PubMed]

78. D’Andrea, M.R.; Derian, C.K.; Leturcq, D.; Baker, S.M.; Brunmark, A.; Ling, P.; Darrow, A.L.; Santulli, R.J.; Brass, L.F.; Andrade-Gordon, P. Characterization of Protease-activated Receptor-2 Immunoreactivity in Normal Human Tissues. J. Histochem. Cytochem. 1998, 46, 157-164. [CrossRef]

79. Chen, K.; Zhang, Z.-F.; Liao, M.-F.; Yao, W.-L.; Wang, J.; Wang, X.-R. Blocking PAR2 attenuates oxaliplatin-induced neuropathic pain via TRPV1 and releases of substance P and CGRP in superficial dorsal horn of spinal cord. J. Neurol. Sci. 2015, 352, 62-67. [CrossRef] 
80. Vergnolle, N.; Bunnett, N.W.; Sharkey, K.A.; Brussee, V.; Compton, S.J.; Grady, E.F.; Cirino, G.; Gerard, N.; Basbaum, A.I.; Andrade-Gordon, P.; et al. Proteinase-activated receptor-2 and hyperalgesia: A novel pain pathway. Nat. Med. 2001, 7, 821-826. [CrossRef]

81. Gillet, L.; Roger, S.; Besson, P.; Lecaille, F.; Gore, J.; Bougnoux, P.; Lalmanach, G.; Le Guennec, J.-Y. Voltage-gated Sodium Channel Activity Promotes Cysteine Cathepsin-dependent Invasiveness and Colony Growth of Human Cancer Cells. J. Biol. Chem. 2009, 284, 8680-8691. [CrossRef]

82. Chung, K.; Pitcher, T.; Grant, A.D.; Hewitt, E.; Lindstrom, E.; Malcangio, M. Cathepsin S acts via protease-activated receptor 2 to activate sensory neurons and induce itch-like behaviour. Neurobiol. Pain 2019, 6, 100032. [CrossRef]

83. Clark, A.K.; Yip, P.K.; Grist, J.; Gentry, C.; Staniland, A.A.; Marchand, F.; Dehvari, M.; Wotherspoon, G.; Winter, J.; Ullah, J.; et al. Inhibition of spinal microglial cathepsin $\mathrm{S}$ for the reversal of neuropathic pain. Proc. Natl. Acad. Sci. USA 2007, 104, 10655-10660. [CrossRef]

84. Clark, A.K.; Malcangio, M. Fractalkine/CX3CR1 signaling during neuropathic pain. Front. Cell. Neurosci. 2014, 8. [CrossRef]

85. Petanceska, S.; Canoll, P.; Devi, L.A. Expression of Rat Cathepsin S in Phagocytic Cells. J. Biol. Chem. 1996, 271, 4403-4409. [CrossRef]

86. Barclay, J.; Clark, A.K.; Ganju, P.; Gentry, C.; Patel, S.; Wotherspoon, G.; Buxton, F.; Song, C.; Ullah, J.; Winter, J.; et al. Role of the cysteine protease cathepsin $S$ in neuropathic hyperalgesia. Pain 2007, 130, $225-234$. [CrossRef]

87. Schwarz, G.; Weber, E.; Schmid, H.; Schwarz, G.; Braun, M.; Schröter, C.J.; Burster, T.; Flad, T.; Dressel, D.; Kalbacher, H. Cathepsin S Activity is Detectable in Human Keratinocytes and is Selectively Upregulated upon Stimulation with Interferon- $\gamma$. J. Investig. Dermatol. 2002, 119, 44-49. [CrossRef]

88. Sudarsanam, S.; Virca, G.D.; March, C.J.; Srinivasan, S. An approach to computer-aided inhibitor design: Application to cathepsin L. J. Comput. Aided Mol. Des. 1992, 6, 223-233. [CrossRef]

89. Komatsu, N.; Takata, M.; Otsuki, N.; Toyama, T.; Ohka, R.; Takehara, K.; Saijoh, K. Expression and Localization of Tissue Kallikrein mRNAs in Human Epidermis and Appendages. J. Investig. Dermatol. 2003, 121, 542-549. [CrossRef]

90. Komatsu, N.; Saijoh, K.; Sidiropoulos, M.; Tsai, B.; Levesque, M.A.; Elliott, M.B.; Takehara, K.; Diamandis, E.P. Quantification of Human Tissue Kallikreins in the Stratum Corneum: Dependence on Age and Gender. J. Investig. Dermatol. 2005, 125, 1182-1189. [CrossRef]

91. Stefansson, K.; Brattsand, M.; Roosterman, D.; Kempkes, C.; Bocheva, G.; Steinhoff, M.; Egelrud, T. Activation of Proteinase-Activated Receptor-2 by Human Kallikrein-Related Peptidases. J. Investig. Dermatol. 2008, 128, 18-25. [CrossRef]

92. Macfarlane, S.R.; Sloss, C.M.; Cameron, P.; Kanke, T.; McKenzie, R.C.; Plevin, R. The role of intracellular $\mathrm{Ca} 2+$ in the regulation of proteinase-activated receptor-2 mediated nuclear factor kappa B signalling in keratinocytes. Br. J. Pharmacol. 2005, 145, 535-544. [CrossRef]

93. Cormia, F.E.; Dougherty, J.W. Proteolytic Activity in Development of Pain and Itching. J. Investig. Dermatol. 1960, 35, 21-26. [CrossRef]

94. Nauroy, P.; Nyström, A. Kallikreins: Essential epidermal messengers for regulation of the skin microenvironment during homeostasis, repair and disease. Matrix Biol. Plus 2020, 6-7, 100019. [CrossRef]

95. Oikonomopoulou, K.; Hansen, K.K.; Saifeddine, M.; Vergnolle, N.; Tea, I.; Blaber, M.; Blaber, S.I.; Scarisbrick, I.; Diamandis, E.P.; Hollenberg, M.D. Kallikrein-mediated cell signalling: Targeting proteinase-activated receptors (PARs). Biol. Chem. 2006, 387. [CrossRef] [PubMed]

96. Ramachandran, R.; Eissa, A.; Mihara, K.; Oikonomopoulou, K.; Saifeddine, M.; Renaux, B.; Diamandis, E.; Hollenberg, M.D. Proteinase-activated receptors (PARs): Differential signalling by kallikrein-related peptidases KLK8 and KLK14. Biol. Chem. 2012, 393, 421-427. [CrossRef]

97. Huang, Z.-J.; Li, H.-C.; Cowan, A.A.; Liu, S.; Zhang, Y.-K.; Song, X.-J. Chronic compression or acute dissociation of dorsal root ganglion induces cAMP-dependent neuronal hyperexcitability through activation of PAR2. Pain 2012, 153, 1426-1437. [CrossRef]

98. Hidalgo, J.; Liberona, J.L.; Molgó, J.; Jaimovich, E. Pacific ciguatoxin-1b effect over Na+and K+currents, inositol 1,4,5-triphosphate content and intracellular Ca 2+signals in cultured rat myotubes. Br. J. Pharmacol. 2002, 137, 1055-1062. [CrossRef] 
99. Liberona, J.L.; Cárdenas, J.C.; Reyes, R.; Hidalgo, J.; Molgó, J.; Jaimovich, E. Sodium-dependent action potentials induced by brevetoxin-3 trigger both IP3 increase and intracellular Ca2+ release in rat skeletal myotubes. Cell Calcium 2008, 44, 289-297. [CrossRef]

100. Heller, S.; O'Neil, R.G. Molecular Mechanisms of TRPV4 Gating. In TRP Ion Channel Function in Sensory Transduction and Cellular Signaling Cascades; Liedtke, W.B., Heller, S., Eds.; Frontiers in Neuroscience; CRC Press/Taylor \& Francis: Boca Raton, FL, USA, 2007; pp. 113-125. ISBN 978-0-8493-4048-2.

101. Dunn, K.M.; Hill-Eubanks, D.C.; Liedtke, W.B.; Nelson, M.T. TRPV4 channels stimulate Ca2+-induced Ca2+ release in astrocytic endfeet and amplify neurovascular coupling responses. Proc. Natl. Acad. Sci. USA 2013, 110, 6157-6162. [CrossRef]

102. Dahan, D.; Ducret, T.; Quignard, J.-F.; Marthan, R.; Savineau, J.-P.; Estève, E. Implication of the ryanodine receptor in TRPV4-induced calcium response in pulmonary arterial smooth muscle cells from normoxic and chronically hypoxic rats. Am. J. Physiol. Lung Cell. Mol. Physiol. 2012, 303, L824-L833. [CrossRef]

103. Boehmerle, W.; Huehnchen, P.; Lee, S.L.L.; Harms, C.; Endres, M. TRPV4 inhibition prevents paclitaxel-induced neurotoxicity in preclinical models. Exp. Neurol. 2018, 306, 64-75. [CrossRef]

104. Lundberg, J.M.; Martling, C.-R.; Saria, A. Substance P and capsaicin-induced contraction of human bronchi. Acta Physiol. Scand. 1983, 119, 49-53. [CrossRef]

105. Barnes, P.J.; Baraniuk, J.N.; Belvisi, M.G. Neuropeptides in the Respiratory Tract: Part, I. Am. Rev. Respir. Dis. 1991, 144, 1187-1198. [CrossRef]

106. Su, X.; Camerer, E.; Hamilton, J.R.; Coughlin, S.R.; Matthay, M.A. Protease-activated receptor-2 activation induces acute lung inflammation by neuropeptide-dependent mechanisms. J. Immunol. 2005, 175, 2598-2605. [CrossRef]

107. Ollerenshaw, S.L.; Jarvist, D.; Sullivan, C.E.; Woolcock, A.J. Substance P immunoreactive nerves in airways from asthmatics and nonasthmatics. Eur. Respir. J. 1991, 4, 673-682.

Publisher's Note: MDPI stays neutral with regard to jurisdictional claims in published maps and institutional affiliations.

(C) 2020 by the authors. Licensee MDPI, Basel, Switzerland. This article is an open access article distributed under the terms and conditions of the Creative Commons Attribution (CC BY) license (http://creativecommons.org/licenses/by/4.0/). 